AUG 191952

\title{
Physical Properties of Some
}

Samples of Asbestos-Cement Siding

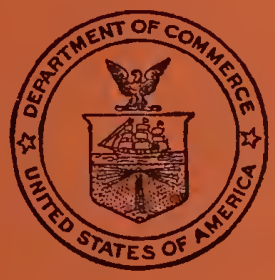

United States Department of Commerce

National Bureau of Standards

Building Materials and Structures Report 122 


\section{BUILDING MATERIALS AND STRUCTURES REPORTS}

On request, the Superintendent of Documents, U. S. Government Printing Office, Washington $25, \mathrm{D}$. C., will place your name on a special mailing list to receive notices of new reports in this series as soon as they are issued. There will be no charge for receiving such notices.

An alternative method is to deposit with the Superintendent of Documents the sum of $\$ 5$, with the request that the reports be sent to you as soon as issued, and that the cost thereof be charged against your deposit. This will provide for the mailing of the publications without delay. You will be notified when the amount of your deposit has become exhausted.

If 100 copies or more of any report are ordered at one time, a discount of 25 percent is allowed. Send all orders and remittauces to the Superintendent of Documents, U.S. Government Printing Office, Washington 25, D. C.

The following publications in this series are available by purchase from the Superintendent of Documents at the prices indicated:

BMS1 Research on Building Materials and Structures for Use in Low-Cost Housing

BMS2

BMS3

BMS4

BMS5

BMS6

BMS7

BMS8

BMS9

Methods of Determining the Structural Properties of Low-Cost House Constructions...

Suitability of Fiber Insulating Lath as a Plaster Base.

Accelerated Aging of Fiber Building Boards

Structural Properties of Six Masonry Wall Constructions

Survey of Roofing Materials in the Southeastern States

Water Permeability of Masonry Walls

Methods of Investigation of Surface Treatment for Corrosion Protection of Steel

Structural Properties of the Insulated Steel Construction Co.'s "Frameless-Steel" Constructions for Walls, Partitions, Floors, and Roofs

BMS10 Structural Properties of One of the "Keystone Beam Steel Floor" Constructions

BMS11 Structural Properties of the Curren Fabrihome Corporation's "Fabrihome" Con-

BMS12 Structural Properties of "Steelox" Constructions for Walls, Partitions, Floors, and

Roofs Sponsored by Steel Buildings, Inc
BMS13 Properties of Some Fiber Building Boards of Current Manufacture.

BMS14 Indentation and Recovery of Low-Cost Floor Coverings by the Wheeling Corrugating Co

BMS16 Structural Properties of a "Tilecrete" Floor Construction Sponsored by Tilecrete Floors, Inc...

BMS17 Sound Insulation of Wall and Floor Constructions

Supplement to BMS17, Sound Insulation of Wall and Floor Constructions

Supplement No. 2 to BMS17, Sound Insulation of Wall and Floor Constructions

BMS18 Structural Properties of "Pre-fab" Constructions for Walls, Partitions, and Floors Sponsored by the Harnischfeger Corporation

BMS19 Preparation and Revision of Building Codes

BMS21 Structural Properties of a Concrete-Block Cavity-Wall Construction Sponsored by

the National Concrete Masonry Association

BMS23 Structural Properties of a Brick Cavity-Wall Construction Sponsored by the Brick Manufacturers Association of New York, Inc-
all Construction and a Brick-Tile

BMS24 Structural Properties of a Reinforced-Brick Wall Construction and a Brick-Tile

BMS25 Structural Properties of Conventional Wood-Frame Constructions for Walls, Partitions, Floors, and Roofs

BMS26 Structural Properties of "Nelson Pre-Cast Concrete Foundation" Wall Construction Sponsored by the Nelson Cement Stone Co., Inc

BMS27 Structural Properties of "Bender Steel Home" Wall Construction Sponsored by the Bender Body Co

BMS28 Backflow Prevention in Over-Rim Water Supplies

$\begin{array}{ll}\text { BMS29 } & \text { Survey of Roofing Materials in the Northeastern States.- } \\ \text { BMS30 Structural Properties of a Wood-Frame Wall Construction Sponsored by the }\end{array}$

Douglas Fir Plywood Association
BMS31 Structural Properties of "Insulite" Wall and "Insulite" Partition Constructions Sponsored by the Insulite Co

- Out of print.

† Superseded by BMs116.

[List continued on cover page III] $20 \phi$ $15 \phi$ 


\title{
Physical Properties of Some Samples of Asbestos-Cement Siding
}

\author{
Cyrus C. Fishburn
}

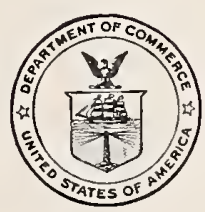

Building Materials and Structures Report 122

Issued July 6, 1951 


\section{Foreword}

This report gives the physical properties of some samples of American asbestos-cement siding and briefly discusses similar data contained in a recent British report on the effects of natural and artificial weathering of asbestoscement roofing. In this country, asbestos-cement building products have had, in the past, a satisfactory durability record on exposure to natural weathering. The information in this paper may be of interest and value to specification writers and to the users of asbestos-cement siding.

E. U. Condon, Lirector. 


\section{GONTENTS}

Foreword

1. Introduction

II. Siding samples

1. General description

2. Preparation and marking of specimens $\ldots \ldots$

III. Tests of the siding samples and discussion of test results $\ldots \ldots \ldots$

1. Thickness and other dimensions _................... 3

2. Water absorption $\ldots$

3. Density and porosity $\ldots \ldots \ldots$

(a) Specific gravity 5

(b) Amount of voids $\ldots \ldots \ldots$

4. Dimensional stability _........................... 6

(a) Linear expansion on exposure to high-pressure steam_.. - 6

(b) Linear change in wetting and drying $\ldots \ldots$

(c) Warping ...

5. Flexural strength and extensibility under flexural load _... 9

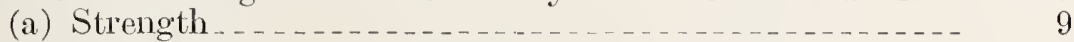

(b) Extensibility

(c) Modulus of elasticity $\ldots$

IV. Tests made by the British Building Research Board $\ldots$

1. Laboratory measurements

(a) Flexure tests $\ldots$

(b) Tensile tests

(c) Impact tests

(d) Water absorption 12

(e) Moisture movement 13

2. Effects of natural weathering

3. Effects of accelerated weathering _...

(a) Wetting and drying 13

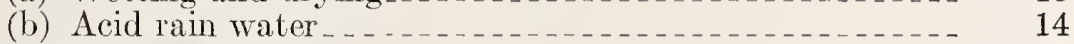

(c) Frost action

V. Conclusions 


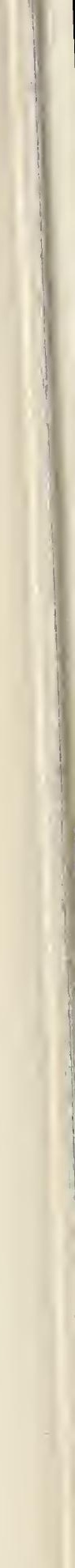




\title{
Physical Properties of Some Samples of Asbestos-Cement Siding
}

\author{
Cyrus C. Fishburn
}

\begin{abstract}
Measurements were made of the water absorption, weight, porosity, dimensional stability, flexural strength, and flexibility of 23 samples of Ameriean asbestos-cement siding furnished by eight manufacturers. A report of an investigation on the weathering of British asbestos-eement rooflng produets was studied and is briefly reported in this paper.

The modulus of elastieity of the siding samples inereased with deerease in absorption. The British investigation indicated that samples of roofing produets having a high resistanee to freezing and thawing also had low absorption and high modulus of elasticity. Slight deerease In length and in moisture movement were noted with repeated eyeles of wetting and drying.
\end{abstract}

\section{In troduction}

The large-scale manufacturc of asbestos-cement shingles began in Europe during the 1890's through the invention of the wet, or laminated Hatschck process. Shortly after 1900 , this process was used and protected by patent in the United States. The birth of the shingle industry in the United States was coincident with the initial rise in the production of portland cement.

In the Hatschck process, the wet solids from a mixture of cement, asbestos, and water, of thin consistency, are picked up on a wire screen and transferred from a cloth belt to a rotating smooth cylinder that builds up the stock to the desired thickness. The resulting cylindrical tube is slit, peeled from the cylinder to form a flat sheet, cut into smaller slabs, and hydraulically pressed. In 1907 , patents were issued in the United States on a "Dry-Proccss" of making asbestos-ccment shingles. A dry mixture of cement and asbestos is deposited on a moving conveyor, lcveled, pressed, wetted, and then consolidated by hydraulic pressure. Refinements of the two basic processes are being used today. Although asbestos-cement shingles were developed primarily as a rooflng material, they were also used to a limited extent as siding prior to 1932 . In 1932 the first shingles designed particularly for use as siding were manufactured, and since that time siding shingles have becn used in increasing quantities.

The physical propertics of some samples of asbestos-cement sidings were measured to obtain information to devclop methods of testing that may be suitable for use in specifications. The dimensions of the units werc obtained, and tests were made of their water absorption, density, and porosity, dimcnsional stability, and flexural strength. The agreement of the results of the measurements made on different specimens cut from one shingle was uscd to obtain an estimate of the precision of some of the test methods.

Some of the data and conclusions obtained from a British investigation on cement-asbestos roofing materials ${ }^{1}$ are also presented in this papcr. The physical properties of the United States and British products were compared in those cases where similar data were obtained.

\footnotetext{
1 Building liesearch Technical Paper 29, Weathering Tests on AsbestosCement Roofing Materials, Department of Scientific and Industrial Research, Park House 24, Rutland Gate, South Kensington, London S. W. 7 . Eng.
}

\section{Siding Samples}

\section{General Description}

'Twenty-two samples of shingle siding and one sample of clapboard siding were furnished to the Bureau by eight manufacturers of asbestoscement building products. Little or no information was obtained from the manufacturers regarding the methods of making the samples and the kinds and proportions of the materials used in them. Twenty of the 23 samples were woodgrained, 19 were either white or gray in color, and 4 contained pigments or aggregates of colors other than white or gray. Some samples were slightly water repellent and the units in onc sample were highly water repellent on both faces. The exposure face of the units in one sample were treated 
with a white pigmented organic coating. It is probable that some of the samples were subjected to high-pressure steam curing at the place of manufacture.

Each sample is identified in this report by a number, the sample numbers running consecutively in the order that the samples were received at the Bureau. Samples 4 and $4 \mathrm{x}$ of similar units, wcre made at the same plant but were received at different times.

\section{Preparation and Marking of Specimens}

The units in each siding sample were numbered as selected for test, and specimens cut from the units, were marked with the sample number and the unit number. When the dircction of the principal axis of a specimen with relation to the vertical or lorizontal dimension of the unit, as used on the wall, was of importance, the direction was indicated by $A$ or $B$ on the specimen. The long axis of the $A$ specimen was parallel to the verticle dimension of the unit as used on the rvall. The long axis of the $B$ specimen was parallel to the horizontal dimension of the unit. 'The grain ran parallel to the $A$ direction in specimens cut from units whose faces simulated a wood grain. $A$ and $B$ are used through the remainder of the text without further definition.

Specimens were cut to the proper size and shape with a $1 / 8$-in.-thick silicon-carbide cut-off wheel. A diamond saw was used to trim the ends of some specimens.

\section{Tests of the Siding Samples and Discussion of Test Results}

Tèsts were made on like groups of specimens cut from all the samples. Only in table 1, which lists the dimensions, are the data presented in full, for all samples. In tables 2 to 15 , inclusive, the data are given only for the samples representing the maximum, the minimum, and the normal, or an intermediate, value of the property or function under consideration. The selection of the normal, or intermediate, sample was an arbitrary one, based on no fixed rule.

The precision of a method depends upon the degree of consistency among repeated measurements. This is usually weighed either in terms of the standard deviation or in terms of the coefficient of variation. The coefficient of variation may be defined as the ratio of the standard deviation to the average or arithmetic mean. Where, as in this investigation, the number of measurements on a shingle unit or the number of specimens cut from a shingle is limited, it is desirable to combine the information obtaincd from several shingles. This combination is done by the technique described in H. A. Freeman's Industrial statistics, formula 1, p. 58. The formula gives the standard deviation or precision of an individual measurement about its mean for a shingle. The precision of a test procedure, or test method is $1 / \sqrt{n}$ times the precision determined from equation 1 ; the symbol $n$ represents the number of determinations per shingle. The lower the value for the precision as determined above, the better the agreement among the measurements.

The variability among different shingles, taken at random and representing a sample, may be determined by computing the standard deviation of the shingle averages about the grand average, as in formula 2, p. 59 of Industrial statistics. A judgment of the adequacy of a test method may be made by comparing the precision of the test method with the variability of the shingles. 'The variability of shingle averages and the precision of the test method are given in this paper for measurements of shingle thickness by three different methods and for the water absorption of the shingles. The variability of shingle averages, alone, are given for other data. Throughout the paper, the coefficient of variation is used instead of the standard deviation.

It slould be understood that error in meastirement in the tests is included in the variability of the shingles. The variability among shingle averages listed in the paper are not corrected ${ }^{2}$ for the precision of the test method.

\footnotetext{
2 The corrected variability of the shingle average would be $\sqrt{(\text { variability of shingle average })^{2}-(\text { precision of test method })^{2}}$.
} 
TABLE 1. Dimensions a of siding shingles and clapboards.

\begin{tabular}{|c|c|c|c|c|c|c|c|c|c|c|c|c|c|c|c|c|}
\hline \multirow{2}{*}{$\begin{array}{c}\text { Sam- } \\
\text { ple }\end{array}$} & \multirow{2}{*}{$\begin{array}{l}\text { Width, } \\
\text { W }\end{array}$} & \multicolumn{2}{|c|}{ Height, } & \multicolumn{3}{|c|}{ Thickness b } & \multirow{2}{*}{$\begin{array}{l}\text { Num- } \\
\text { ber of } \\
\text { nail } \\
\text { holes }\end{array}$} & \multicolumn{2}{|c|}{$\begin{array}{l}\text { Dianeter of } \\
\text { nail holes }\end{array}$} & \multicolumn{2}{|c|}{$\begin{array}{l}\text { Average dis- } \\
\text { tunce of nail } \\
\text { holes from } \\
\text { top edge }\end{array}$} & \multicolumn{2}{|c|}{$\begin{array}{l}\text { A verage dis- } \\
\text { tance of nail } \\
\text { holes from } \\
\text { side of shill- } \\
\text { gles }\end{array}$} & \multicolumn{2}{|c|}{ Lap } & \multirow{2}{*}{$\begin{array}{l}\text { Gros: } \\
\text { area }\end{array}$} \\
\hline & & $\max$ & $\min$ & $\max$ & $\min$ & $\begin{array}{l}\text { Aver- } \\
\text { age c }\end{array}$ & & $\begin{array}{l}\text { Top } \\
\text { holes }\end{array}$ & $\begin{array}{l}\text { Bot- } \\
\text { tom } \\
\text { holes }\end{array}$ & $\begin{array}{l}\text { Top } \\
\text { holes }\end{array}$ & $\begin{array}{l}\text { Bot- } \\
\text { tom } \\
\text { holes }\end{array}$ & $\begin{array}{c}\text { Top } \\
\text { holes }\end{array}$ & $\begin{array}{l}\text { Bot- } \\
\text { tom } \\
\text { holes }\end{array}$ & $\max$ & $\min$ & \\
\hline I & 2 & 3 & 4 & 5 & 6 & 7 & 8 & 9 & 10 & 11 & 12 & 13 & 14 & 15 & 16 & 17 \\
\hline $\begin{array}{l}1 \\
2 \\
3 \\
4 \mathrm{~d} \\
4 \mathrm{x}^{\mathrm{d}}\end{array}$ & $\begin{array}{c}\text { in. } \\
23.99 \\
24.00 \\
23.99 \\
24.00 \\
23.99\end{array}$ & $\begin{array}{c}\text { in. } \\
12.00 \\
12.02 \\
12.02 \\
12.01 \\
12.00\end{array}$ & $\begin{array}{l}\text { in. } \\
11.76 \\
11.80 \\
11.81 \\
11.75 \\
11.72\end{array}$ & $\begin{array}{c}\text { in. } \\
0.163 \\
.166 \\
.159 \\
.158 \\
.149\end{array}$ & $\begin{array}{c}\text { in. } \\
0.118 \\
.143 \\
.113 \\
.134 \\
.123\end{array}$ & $\begin{array}{l}\text { in. } \\
0.15 \\
.17 \\
.16 \\
.14 \\
.14\end{array}$ & $\begin{array}{r}i n . \\
6 \\
6 \\
6 \\
5 \\
5\end{array}$ & $\begin{array}{l}\text { in. } \\
0.11 \\
.10 \\
.11 \\
.11 \\
.10\end{array}$ & $\begin{array}{l}\text { in } \\
0.16 \\
.15 \\
.16 \\
.15 \\
.15\end{array}$ & $\begin{array}{l}\text { in } \\
0.71 \\
.76 \\
.84 \\
.83 \\
.82\end{array}$ & $\begin{array}{c}\text { in. } \\
10.49 \\
10.49 \\
10.44 \\
10.49 \\
10.49\end{array}$ & $\begin{array}{l}i n . \\
1.01 \\
1.01 \\
1.39 \\
3.02 \\
3.02\end{array}$ & $\begin{array}{l}\text { in. } \\
\text { 1. } 38 \\
\text { 1. } 55 \\
1.38 \\
1.40 \\
1.40\end{array}$ & $\begin{array}{l}\text { in. } \\
\text { 1. } 48 \\
1.47 \\
1.53 \\
1.44 \\
1.45\end{array}$ & $\begin{array}{l}\text { in. } \\
1.21 \\
1.25 \\
1.31 \\
1.20 \\
1.20\end{array}$ & $\begin{array}{l}f t .2 \\
1.98 \\
1.98 \\
1.93 \\
1.93 \\
1.93\end{array}$ \\
\hline $\begin{array}{l}5 \\
6 \\
7 \\
8 \\
9 \text { e }\end{array}$ & $\begin{array}{l}27.01 \\
26.90 \\
23.99 \\
23.98 \\
96.02\end{array}$ & $\begin{array}{r}12.01 \\
12.00 \\
12.00 \\
12.00 \\
9.50\end{array}$ & $\begin{array}{r}11.63 \\
11.60 \\
11.78 \\
11.78 \\
9.48\end{array}$ & $\begin{array}{l}.159 \\
.154 \\
.194 \\
.195 \\
.196\end{array}$ & $\begin{array}{l}.136 \\
.130 \\
.181 \\
.185 \\
.196\end{array}$ & $\begin{array}{l}.15 \\
.14 \\
.18 \\
.19 \\
.19\end{array}$ & $\begin{array}{r}6 \\
6 \\
5 \\
5 \\
14\end{array}$ & $\begin{array}{l}.10 \\
.09 \\
.10 \\
.10 \\
.11\end{array}$ & $\begin{array}{l}.15 \\
.15 \\
.15 \\
.15 \\
.15\end{array}$ & $\begin{array}{r}.75 \\
.77 \\
.82 \\
.82 \\
1.02\end{array}$ & $\begin{array}{r}10.44 \\
10.42 \\
10.46 \\
10.46 \\
7.95\end{array}$ & $\begin{array}{l}1.02 \\
1.00 \\
2.98 \\
2.99 \\
0.57\end{array}$ & $\begin{array}{l}2.02 \\
2.00 \\
1.39 \\
1.38 \\
0.57\end{array}$ & $\begin{array}{l}1.52 \\
1.51 \\
1.50 \\
1.51 \\
1.55\end{array}$ & $\begin{array}{l}1.14 \\
1.15 \\
1.27 \\
1.27 \\
1.50\end{array}$ & $\begin{array}{l}2.21 \\
2.21 \\
1.98 \\
1.98 \\
6.33\end{array}$ \\
\hline $\begin{array}{l}10 \\
11 \\
12 \\
13 \\
14\end{array}$ & $\begin{array}{l}23.96 \\
24.00 \\
24.00 \\
24.00 \\
23.99\end{array}$ & $\begin{array}{l}12.01 \\
12.04 \\
12.00 \\
12.00 \\
12.00\end{array}$ & $\begin{array}{l}11.84 \\
11.86 \\
12.00 \\
12.00 \\
11.70\end{array}$ & $\begin{array}{l}.170 \\
.169 \\
.134 \\
.139 \\
.152\end{array}$ & $\begin{array}{l}.152 \\
.150 \\
.134 \\
.139 \\
.137\end{array}$ & $\begin{array}{l}.15 \\
.16 \\
.13 \\
.14 \\
.15\end{array}$ & $\begin{array}{l}6 \\
6 \\
5 \\
5 \\
6\end{array}$ & $\begin{array}{l}.10 \\
.11 \\
.10 \\
.11 \\
.11\end{array}$ & $\begin{array}{l}.13 \\
.14 \\
.14 \\
.15 \\
.15\end{array}$ & $\begin{array}{r}0.77 \\
.77 \\
.76 \\
.79 \\
.75\end{array}$ & $\begin{array}{l}10.46 \\
10.48 \\
10.42 \\
10.46 \\
10.67\end{array}$ & $\begin{array}{r}.98 \\
.99 \\
3.02 \\
3.04 \\
1.50\end{array}$ & $\begin{array}{l}1.99 \\
2.00 \\
1.40 \\
1.38 \\
1.50\end{array}$ & $\begin{array}{l}1.51 \\
1.50 \\
1.53 \\
1.51 \\
1.29\end{array}$ & $\begin{array}{l}1.33 \\
1.30 \\
1.52 \\
1.45 \\
0.98\end{array}$ & $\begin{array}{l}\mathbf{1} .98 \\
1.99 \\
2.00 \\
2.00 \\
\mathbf{1 . 9 7}\end{array}$ \\
\hline $\begin{array}{l}15 \\
16 \\
17 \\
18 \\
19\end{array}$ & $\begin{array}{l}23.99 \\
23.99 \\
23.98 \\
24.00 \\
24.04\end{array}$ & $\begin{array}{l}12.00 \\
11.76 \\
11.76 \\
12.01 \\
12.03\end{array}$ & $\begin{array}{l}11.70 \\
11.45 \\
11.46 \\
11.75 \\
11.77\end{array}$ & $\begin{array}{l}167 \\
.161 \\
.179 \\
150 \\
.154\end{array}$ & $\begin{array}{l}.149 \\
.145 \\
.165 \\
.130 \\
.125\end{array}$ & $\begin{array}{l}.16 \\
.15 \\
.17 \\
.14 \\
.15\end{array}$ & $\begin{array}{l}6 \\
6 \\
6 \\
5 \\
5\end{array}$ & $\begin{array}{l}.11 \\
.12 \\
.12 \\
.10 \\
.10\end{array}$ & $\begin{array}{l}.15 \\
.12 \\
.11 \\
.16 \\
.15\end{array}$ & $\begin{array}{r}.75 \\
1.07 \\
1.08 \\
0.77 \\
.77\end{array}$ & $\begin{array}{l}10.66 \\
10.42 \\
10.43 \\
10.46 \\
10.47\end{array}$ & $\begin{array}{l}\text { 1. } 50 \\
\text { 1. } 50 \\
\text { 1. } 50 \\
\text { 3. } 02 \\
\text { 3. } 02\end{array}$ & $\begin{array}{l}1.50 \\
1.52 \\
1.52 \\
1.49 \\
1.53\end{array}$ & $\begin{array}{l}1.28 \\
1.28 \\
1.28 \\
1.50 \\
1.50\end{array}$ & $\begin{array}{r}.99 \\
.97 \\
.98 \\
1.24 \\
1.26\end{array}$ & $\begin{array}{l}1.97 \\
1.95 \\
1.95 \\
1.98 \\
1.98\end{array}$ \\
\hline $\begin{array}{l}20 \\
21 \\
22 \\
23\end{array}$ & $\begin{array}{l}24.00 \\
24.01 \\
24.03 \\
23.98\end{array}$ & $\begin{array}{l}12.01 \\
12.02 \\
12.02 \\
12.02\end{array}$ & $\begin{array}{l}11.75 \\
11.76 \\
11.77 \\
11.75\end{array}$ & $\begin{array}{l}.159 \\
.151 \\
.155 \\
.156\end{array}$ & $\begin{array}{l}.141 \\
.136 \\
.131 \\
.131\end{array}$ & $\begin{array}{l}.15 \\
.14 \\
.15 \\
.15\end{array}$ & $\begin{array}{l}5 \\
5 \\
5 \\
5\end{array}$ & $\begin{array}{l}.10 \\
.10 \\
.10 \\
.10\end{array}$ & $\begin{array}{l}.16 \\
.16 \\
.14 \\
.15\end{array}$ & $\begin{array}{l}.77 \\
.76 \\
.77 \\
.82\end{array}$ & $\begin{array}{l}\text { 10. } 46 \\
\text { 10. } 47 \\
10.48 \\
10.46\end{array}$ & $\begin{array}{l}\text { 3. } 00 \\
\text { 3. } 01 \\
\text { 3. } 02 \\
\text { 3. } 01\end{array}$ & $\begin{array}{l}1.50 \\
1.50 \\
1.51 \\
1.39\end{array}$ & $\begin{array}{l}1.28 \\
\text { 1. } 50 \\
1.47 \\
1.52\end{array}$ & $\begin{array}{l}1.24 \\
1.25 \\
1.25 \\
1.23\end{array}$ & $\begin{array}{l}1.98 \\
1.98 \\
1.98 \\
1.98\end{array}$ \\
\hline
\end{tabular}

a Unless otherwise noted, the values are an average of measurements on 10 shingle units and' 3 clapboard units.

b The values arc an average of 9 observations on each of 5 shingle units and of 14 observations on each of 5 clapboard units. c Average values observed by a water displaeement inethod on a different group of specimens.

d Samples 4 and $4 \mathrm{x}$ were two different shipments of similar units.

- Sample of clapboards.

\section{Thickness and other dimensions}

The thickness of the samples was measured by three different methods:

Method 1. The thicknesses of five whole units taken at random from each samplc were measured with a micrometer dial reading to 0.001 in. for each division of the dial. 'The plunger on the dial was fitted with a sharp point, and the dial was mounted in a vertical position on a metal base. A ball bearing was fixed in the base directly below the dial plunger, and the projecting top of the bearing was machined to a horizontal surface having a diameter of $0.1 \mathrm{in}$. The units were moved over the bearing with their faces upward, and both the maximum and the minimum thicknesses of the units were measured at each of nine places on each shingle unit, and at 14 places on each clapboard unit. The places where the measurements were made were spaced symmetrically about the units so that a general avcrage of the maximum and minimum thicknesses could be obtained. The thicknesses obtained by this method are listed in columns 5 and 6 of table 1 .

Method 2. The maximum thickness of each sample was measured in a manner similar to one once proposed for use in Fedcral spccifications. Twenty $A$ and $20 B$ specimens 6 by 12 in. in size were cut from different units taken from each shingle sample. They were placed, one at a time, between steel plates $3 / 8$ by 6 by 12 in. with polished parallel faces. The over-all thickness of the plates and specimen was measured with a micrometer caliper. Four observations were made on each specimen, the micrometer caliper being placed at the midpoint of each side and near the edges of the plates. 'The average maximum thickness of the samples obtained in this manner is listed for samples 6 , 12 , and 16 in column 2 of table 2 . The differcnces between the maximum thicknesses of the samples obtained by methods 1 and 2 are listed in column 3 of table 2. 
'TABLE 2. Comparison of maximum thickness obtained by methods 2 and 1

\begin{tabular}{|l|c|c|}
\hline Sample & $\begin{array}{c}\text { Average } \\
\text { maximum } \\
\text { thickness } \\
\text { determined } \\
\text { by } \\
\text { method 2 a }\end{array}$ & $\begin{array}{c}\text { Aparent differ- } \\
\text { ence in } \\
\text { maximum } \\
\text { thickness meas- } \\
\text { ured by } \\
\text { methods } 1 \text { and } \\
2 \text { b }\end{array}$ \\
\hline 6 (max) & Inch & Inch \\
12 (min) & 0.241 & 0.087 \\
16 (normal) & .150 & .016 \\
.028
\end{tabular}

a Specimens placed between steel plates and their maximum thickness measured with a micrometer caliper.

b The thicknesses obtained by method 1, listed in column 5 of table 1, are subtracted from the thickness obtained by method 2 .

Method 3. The average thickness of the samples was also measured by a water-displacement method. Ten or more 4 - by 9 -in. specimens were cut from five or more units taken from each sample. These units were not the same as those selected for the maximum and minimum thickness measurements. The specimens, fully saturated, were weighed when suspended in water and when in air. The average thicknesses obtained in this manner are listed in column 7 of table 1 .

'The most precise method of measuring the maximum thickness of the samples was method 1 , in in which a micrometer dial was used. As the pre(rision of the measurements depender directly upon the number of observations, the method was somewhat tedious. The coefficients of variation for the variability of the shingle averages and for the precision of test method 1, are listed below for samples 6,12 , and 16 .

\begin{tabular}{|c|c|c|}
\hline Sample & $\begin{array}{l}\text { Variability } \\
\text { of shingle } \\
\text { averages a }\end{array}$ & $\begin{array}{c}\text { Precision of } \\
\text { test } \\
\text { method b }\end{array}$ \\
\hline $\begin{array}{l}6\left\{\begin{array}{l}\max \text { thickness } \\
12{ }_{\min }^{\circ} \text { thickness }\end{array}\right. \\
16\left\{\begin{array}{l}\text { max thickness } \\
\text { min thickness }\end{array}\right.\end{array}$ & $\begin{array}{r}2.7 \\
4.9 \\
1.4 \\
9.9 \\
11.3\end{array}$ & $\begin{array}{l}1.0 \\
1.2 \\
0.8 \\
1.7 \\
1.7\end{array}$ \\
\hline
\end{tabular}

s Based on the variability among 5 shingle averages.

b Based on the variability of 9 determinations per shingle, combined over 5 shingles.

Any curvature of the specimens introduced a positive error in the measurements of thickness by the use of steel plates, method 2. The coefficients of variation for the variability of the shingle averages and for the precision of test method 2 , are listed below.

\begin{tabular}{|c|c|c|}
\hline Sample & $\begin{array}{l}\text { Variability } \\
\text { of shingle } \\
\text { averages a }\end{array}$ & $\begin{array}{c}\text { Precision of } \\
\text { test } \\
\text { method b }\end{array}$ \\
\hline $\begin{array}{l}6\left\{\begin{array}{l}A \\
B\end{array}{ }_{12}, A \text { and } B \text { c }\right. \\
16 \\
A \\
B\end{array}$ & $\begin{array}{l}7.7 \\
4.9 \\
1.9 \\
7.7 \\
5.3\end{array}$ & $\begin{array}{l}2.6 \\
1.9 \\
1.0 \\
1.8 \\
1.7\end{array}$ \\
\hline
\end{tabular}

Based on the variability among 20 shingle averages.

b Based on the variability of 4 determinations per shingle, combined over 6 shingles.
The precision of the test method for maximum shingle thickness obtained by methods 1 and 2 indicates, for samples 6 and 12 , that method 1 was slightly more precise than method 2. Actually, there was a great difference in the maximum thickness of the samples, as measured by the two methods. From table 2 it is clear that method 2 is highly inaccurate. An analysis of the data obtained from all samples indicates that the average positive difference, bias, in thickness between the values obtained by methods 1 and 2 was about 16 percent of the average by method 1 . For sample 6 the difference was over 50 percent. The method of calculating the precision of the test method does not, of course, include the effects of constant errors inherent to a method of measurement. Another important factor regarding method 2 was the difficulty at making steel plates with parallel faces. The plates used in this investigation had a thickness tolerance of \pm 0.0005 in., and it was found necessary to select plates having a thickness of $1 / 2$ in. or more before grinding and polishing their surfaces.

The measurement of average thickness of the samples by water displacement, method 3 , was a simple operation, giving accurate and reproducible results. The coefficients of variation for the variability of the shingle averages and for the precision of test method 3, are listed below for samples 6, 12, and 16 .

\begin{tabular}{|c|c|c|}
\hline Sample & $\begin{array}{c}\text { Variability } \\
\text { of shinglc } \\
\text { averages a }\end{array}$ & $\begin{array}{c}\text { Precision of } \\
\text { test method }\end{array}$ \\
\hline & 5.1 & b 1.8 \\
16 & 0.5 \\
16 & 8.2 & d. \\
\hline
\end{tabular}

a Based on the variability among the different groups of shingle averages. $b$ Based on the variability of 14 determinations combined over 6 shingles. e Based on the variability of 18 determinations combined over 5 shingles.

d Based on the variability of 14 determinations combined over 5 shingles.

Except where the minimum thickness is required to calculate the modulus of rupture, the maximum and the minimum thickness of a wood-grained unit are of little practical interest. The average thickness, determined by method 3 , appears to be a more practicable requirement of specification purposes than the maximum thicknesses determined by either method 1 or 2.

Excepting the large and constant errors inherent in method 2, because of the warping of the specimens, the precision of all test methods is sufficient in the light of the variability of the material tested.

\section{Water Absorption}

The water absorption of the samples was determined from tests of 4 - by 9 -in. specimens cut from five shingles or clapboard units taken from each sample. The specimens were dried to constant weight in an oven at $221^{\circ}$ to $239^{\circ} \mathrm{F}\left(105^{\circ}\right.$ to $115^{\circ}$ 
C). After cooling, they were immersed in water at $70^{\circ} \mathrm{F}\left(21^{\circ} \mathrm{C}\right)$ for periods of $1,3,5,15 \mathrm{~min}$, $1 \mathrm{hr}, 1$ day, 3 days, and 7 days. The absorptions during each of these immersion periods are listed in table 3 for samples 2,10 , and 12 .

TABLE 3. Water absorption a

\begin{tabular}{|c|c|c|c|}
\hline \multirow{2}{*}{ Immersion period } & \multicolumn{3}{|c|}{ Sample } \\
\hline & $\stackrel{2}{2}$ & $\underset{(\min )}{12}$ & $\begin{array}{c}10 \\
\text { (normal) }\end{array}$ \\
\hline $1 \mathrm{~min}$ & $\begin{array}{l}\% \\
3.8\end{array}$ & $\begin{array}{l}\% \\
0.6\end{array}$ & $\%$ \\
\hline 3 min_. & $\begin{array}{l}3.8 \\
7.6\end{array}$ & $\begin{array}{r}.00 \\
.8\end{array}$ & $\begin{array}{l}3.1 \\
4.6\end{array}$ \\
\hline $5 \min _{-}$ & 15.4 & 1.2 & 5.0 \\
\hline $15 \mathrm{~min}$ & 21.4 & 1.8 & 7.4 \\
\hline $1 \mathrm{hr}$ & 25.5 & 3.7 & 11. 8 \\
\hline $1 \mathrm{day}_{-}$ & 27.0 & 10.4 & 15.0 \\
\hline 3 days & 27.7 & 10.8 & 15. 5 \\
\hline 7 daj & 27.9 & 11.0 & 16. 1 \\
\hline
\end{tabular}

- Observed on groups of 5 to 18 specimens cut from 5 different shingles.

The average absorption for all samples during a 7 -day immersion period was 16.2 percent, by dry weight. The maximum absorption was 27.9 percent (sample 2) and the minimum absorption was 11.0 percent (sample 12). For all samples, the absorption during immersion periods of $1 \mathrm{~min}$, $1 \mathrm{hr}$, and 1 day were, respectively, 18, 65, and 93 percent of the absorption during a 7 -day immersion period. A study of the data for all samples indicates that samples having waterrepellant faces or backs had greater than average absorptions during immersion periods of $1 \mathrm{hr} \mathrm{ol}^{\circ}$ less. It follows that, for the initial periods of immersion, most of the water absorbed by the 4by 9 -in. specimens pentrated the cut edges of the specimens. The coefficients of variation for the variability of the shingle averages and the precision of the test method for absorption during a 7-day immersion period are listed below for samples 2,10 , and 12 .

\begin{tabular}{|c|c|c|}
\hline Sample & $\begin{array}{c}\text { Variability } \\
\text { of shingle } \\
\text { a verages a }\end{array}$ & $\begin{array}{c}\text { Precision of } \\
\text { test method }\end{array}$ \\
\hline & & \\
\hline 12 & b 8.8 & \\
10.6 & c 2.8 \\
& 3.3 & 0.9 \\
\hline
\end{tabular}

a Based on the variability among 5 shingle averages.
b Only 1 determination on each of 5 shingles.

c Based on the variability of 18 determinations combincd over 5 shingles. d Based on the variability of 15 determinations combined over 5 shingles.

The same specimens, sample 12 , were used both in the absorption and in the average thickness measurements. An examination of the coefficient of variation data indicates, for this sample, that the variability of the shingles was greater and the agreement among the measurements (precision of test methods) was less for the absorption than for the average thickness.

\section{Density and Porosity}

The specifie gravity and the percentage of voids were determined on groups of 5 to 18 specimens, 4 by 9 in., cut from 5 shingle or clapboard units taken from each sample.

\section{(a) Specific Gravity}

The specimens were dried in an oven at $221^{\circ}$ to $239^{\circ} \mathrm{F}\left(105^{\circ}\right.$ to $\left.115^{\circ} \mathrm{C}\right)$. Volume deterininations were made with a gas-expansion volumenometer. ${ }^{3}$ 'The specific gravities of samples 15 , 13 , and 10 are listed in table 4 .

TABLF 4 . Specific gravity

\begin{tabular}{|c|r|r|}
\hline Sample & $\begin{array}{l}\text { Number of } \\
\text { specimens }\end{array}$ & $\begin{array}{r}\text { Spccific } \\
\text { gravity }\end{array}$ \\
\hline 15 (max) & 13 & 2.64 \\
13 (min) & 18 & 2.41 \\
10 (normal) & 15 & 2.50 \\
\hline
\end{tabular}

\section{(b) Amount of Voids}

The specimens previously used to determine the specific gravity of the samples were immersed in water at $70^{\circ} \mathrm{F}\left(21^{\circ} \mathrm{C}\right)$ for 7 days, and the gross volume of the saturated specimens was calculated from their difference in weight when supported in water and in air. The volume of the voids was found by two methods. In method 1 the voids were determined by comparing the gross volume, obtained as stated above, with the solid volume determined by means of the gas-expansion volumenometer. In method 2 the voids were obtained by comparing the gross volume with the volume of water absorbed during the 7-day immersion period. The volume of the voids, as found by methods 1 and 2 , is listed in table 5 in percentage of the gross volume of samples 2 , 12 , and 10 .

The specific gravity of the samples ranged between 2.39 and 2.64 , and the average value for all samples was 2.48. With few exceptions, those having a high specific gravity also had a low water absorption. Sample 12 was one of the exceptions, having a specific gravity of 2.45 and a minimum water absorption.

As determined by method 2 , the volumes of the voids ranging between 22 and 43 percent of the gross volume, averaged 30-percent, and were about 5 percent higher than the rolumes determined by method 1 , see table 5 . The observed amount of absorbed water was used in determining the voids by method 2 , and the absorption of the samples was almost directly proportional to the amount of voids. The solid volumes of the specimens and their absorptions during the 7-day water immersion were not redeternined after the initial drying and wetting. Some changes in the physical properties of the specimens may

\footnotetext{
3 Joseph C. Richmond, John B. Peterson, and Winslow H. Herschel, An
} improved volumenometer, J. Am. Ceram. Soc. 26, No. 4 (April 1943). 
have occurred as a result of the exposure to drying and wetting, but it is not known how much such changes, if any, affected the amount of voids.

TABLE 5. Tolume of the voids a

\begin{tabular}{|c|c|c|c|}
\hline \multirow{2}{*}{ Sample } & \multirow{2}{*}{$\begin{array}{l}\text { Number of } \\
\text { specimens }\end{array}$} & \multicolumn{2}{|c|}{$\begin{array}{c}\text { Volume a determined } \\
\text { by- }\end{array}$} \\
\hline & & Method 1 b & Method 2 \\
\hline $\begin{array}{l}2(\max ) \\
12(\min ) \\
10(\text { normal })\end{array}$ & $\begin{array}{r}5 \\
18 \\
15\end{array}$ & $\begin{array}{l}\% \\
38 \\
15 \\
26\end{array}$ & $\begin{array}{l}\% \\
43 \\
22 \\
29\end{array}$ \\
\hline
\end{tabular}

a Volume in percentage of the gross volume of the specimens.

b Ratio of the solid volume, as determined by means of a gas-expansion volumenometer, to the gross volume.

c Ratio of the volume of absorbed water to the gross volume.

\section{Dimensional Stability}

\section{(a) Linear Expansion On Exposure To High-Pressure} Steam

A measure of the dimensional stability of the siding shingles was obtained by observing the linear expansion of specimens exposed to highpressure. steam. The specimens were 2 in. wide and $10 \mathrm{in.} \mathrm{long.} A$ pair of specimens, one $A$ and one $B$, was cut from each of five different units taken from each shingle sample. The definition of the $A$ and $B$ specimens is given in section II of this paper.

Changes in length of the specimens were observed with a horizontal dial-micrometer comparator. The comparator, figure 1, consisted of a heavy frame supporting a movable table between two brackets. A micrometer dial supported by one of the brackets was used as a zero indicator. The other bracket supported a 50-thread/in. micrometer screw giving a vernier reading of $0.0001 \mathrm{in}$. The table was fitted with two vertical lifts and crossarms on which the specimens rested. The positions on the brackets of the micrometer dial and screw could be adjusted to fit a range in specimen length from about 8 to $24 \mathrm{in}$. Brasscoated drive screws inserted in the ends and on the longitudinal axis of the specimens provided suitable bearing surfaces between the specimens and the comparator. A flat steel plate of a size and shape similar to those of the specimens was used as a standard bar for the comparator measurements.

The specimens were immersed in water at $70^{\circ} \mathrm{F}$ $\left(21^{\circ} \mathrm{C}\right)$ for 2 days. After removing them from the water, excess surface water was wiped off with a damp cloth, and the initial comparator observations were made. While still damp, the specimens were placed in an autoclave and were subjected to steam at a pressure of 295 psi for $3 \mathrm{hr}$, as prescribed in Federal Specification SS-C-158b, Section F-63d (9). The specimens were then removed from the autoclave, cooled to $70^{\circ} \mathrm{F}$ $\left(21^{\circ} \mathrm{C}\right)$ by immersion in water, and their lengths were determined with the comparator.
TABLE 6. Linear expansion on exposure to high-pressure steam a

\begin{tabular}{|c|c|c|c|}
\hline \multirow{2}{*}{ Sample } & \multicolumn{3}{|c|}{ Linear expansion } \\
\hline & Direction $A^{b}$ & Direction $B \mathrm{c}$ & $\begin{array}{l}\text { Average of } \\
A \text { and } B\end{array}$ \\
\hline $\begin{array}{l}6(\max ) \\
8(\min ) \\
3(\text { normal) } \\
23 \text { (normal) }\end{array}$ & $\begin{array}{r}\text { Percent } \\
0.051 \\
\mathrm{~d}-.001 \\
.030 \\
.027\end{array}$ & $\begin{array}{r}\text { Percent } \\
0.065 \\
.003 \\
.019 \\
.027\end{array}$ & $\begin{array}{r}\text { Percent } \\
0.058 \\
.001 \\
.025 \\
.027\end{array}$ \\
\hline
\end{tabular}

a 3-hour exposure to steam at $295 \mathrm{lb} / \mathrm{in} .^{2}$

$b$ Measured in a direction parallel to the vertical dimension of the shingles as used on the wall. A verage for 5 shingles.

c Measured in a direction parallel to the horizontal dimension of the shingle as used on the wall. A verage for 5 shingles.

d The minus sign indicates a shrinkage.

e A normal sample in which the expansion in one direction was significantly greater than that in the other direction.

A normal sample in which the expansion was about equal in both the $A$ and the $\mathrm{B}$ directions.

The greatest linear expansion of specimens subjected to high-pressure steam was the 0.065 percent observed in the $B$ specimens cut from sample 6 , see table 6 . The $A$ specimens from two samples, 8 and 7 , showed little or no expansion as a result of this exposure. The average expansion for all samples was 0.024 percent in the $A$ direction and 0.023 percent in the $B$ direction. The coefficients of variation for the expansions are listed below for samples $6,8,3$, and 23 .

\begin{tabular}{|c|c|}
\hline Sample & $\begin{array}{l}\text { Variability } \\
\text { of shingle } \\
\text { average }\end{array}$ \\
\hline $\begin{array}{l}6(\max )\left\{\begin{array}{l}A \\
B(\min )\end{array}\left\{\begin{array}{l}A \\
B\end{array} 8 \text { (normal) b }\left\{\begin{array}{l}A \\
B\end{array}\right.\right.\right. \\
23 \text { normal) }\left\{\begin{array}{l}A \\
B\end{array}\right.\end{array}$ & $\begin{array}{r}14 \\
14 \\
340 \\
300 \\
3 \\
8 \\
6 \\
5\end{array}$ \\
\hline
\end{tabular}

a Average for one $A$ and one $B$ specimen cut from each of 5 shingles.

$b$ The expansion in the $A$ direction was 50 percent higher than that in the $B$ direction.

The linear changes noted for sample 8 were about equal to the limits of sensitivity for the observations and are barely significant. The high value for the coefficient of variation reflects this condition. In general, the expansion of the samples may have been dependent upon the incidence of steam curing of the units. There was little or no correlation between the absorption of the samples and the linear expansion on exposure to steam.

\section{(b) Linear Ghange in Wetting and Drying}

The linear changes resulting from the alternate wetting and drying of small specimens cut from the siding units were measured on the comparator (fig. 1) previously described. The specimens were 2 in. wide; those cut from the shingle units were 10 in. long, and those from the clapboard units (sample 9) were 9 in. long. Each sample was 


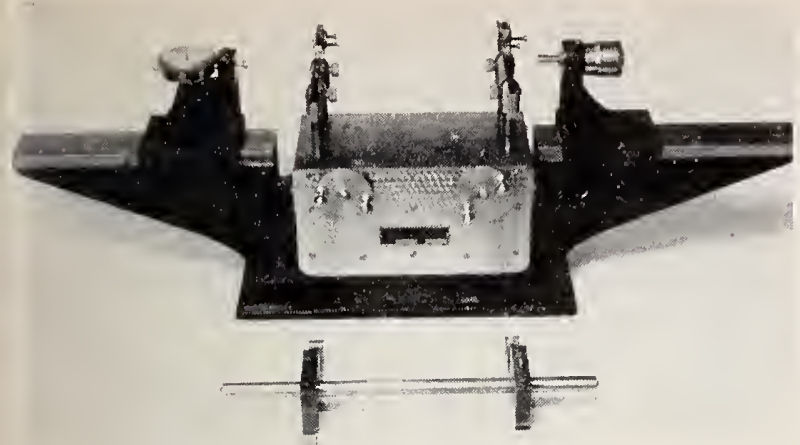

FIgURE 1. The comparator.

A flat plate instead of the round bar was used as a standard bar.

represented by 10 specimens, $5 A$ specimens and $5 B$ specimens. With but few exceptions, only one pair of specimens, $A$ and $B$, were cut from a single unit. Stainlêss-steel drive screws, size 00 by $3 / 16$ in., were inserted in the ends of the specimens in the longitudinal axis and provided suitable noncorrosive contacts between the ends of the specimens and the comparator used to measure the changes in length.
The following procedure was used in testing samples 3 to 23 . Specimens were placed in water at about $70^{\circ} \mathrm{F}\left(21^{\circ} \mathrm{C}\right)$ for 2 days, removed from the water one at a time, wiped with a damp cloth, and initial observations made at once in the comparator. While still wet, the specimens were placed in an oven at $122^{\circ} \mathrm{F}\left(50^{\circ} \mathrm{C}\right)$ for 2 days. On removal from the oven, and while still warm, they were placed in a desiccator containing potassium acetate. The air in the desiccator was at a temperature of about $70^{\circ} \mathrm{F}\left(21^{\circ} \mathrm{C}\right)$ and a relative humidity of about 20 percent. As indicated in table 7 , the specimens usually remained in the desiccator for 1 day before comparator observations were made. Immediately after their removal from the desiccator, the specimens were again placed in water, completing the first cycle. The specimens were subjected to four or five cycles. The specimens representing samples 1 and 2 were subjected to more cycles and to periods of wetting and drying that were of longer duration. The changes in length during these wetting and drying tests are listed in table 7 for samples 14,12 , and 11 , and are based on the initial comparator observations.

TABLE 7. Moisture movement and length change of siding samples on wetting and drying a

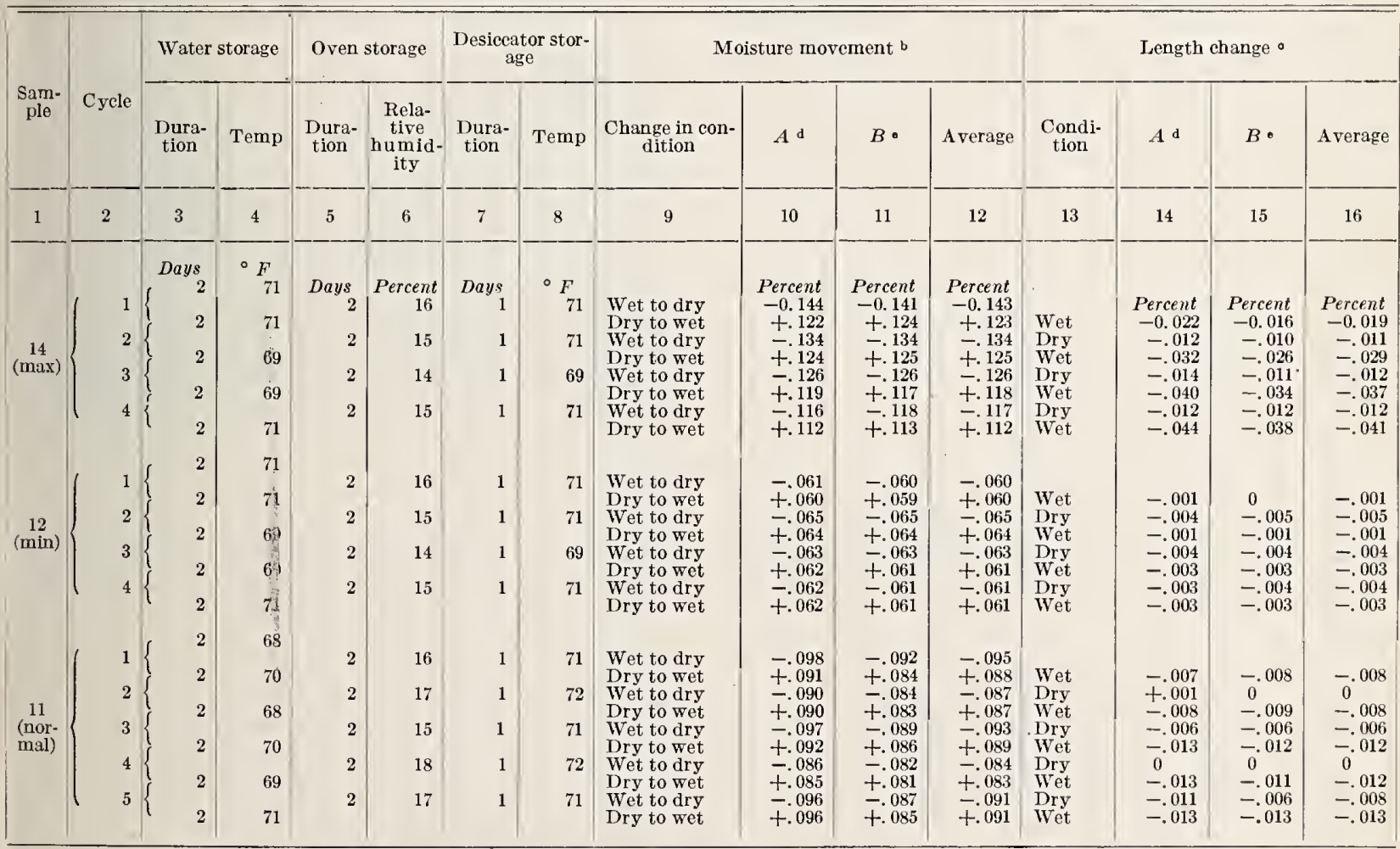

a The cyclical wetting and drying exposure given the specimens was usually as follows: Two days in water at $70^{\circ} \mathrm{F}, 2$ days in an oven at $122^{\circ} \mathrm{F}\left(50^{\circ} \mathrm{F}\right)$ and 1 day in a dessicator at $70^{\circ} \mathrm{F}$.

b The linear change produced by a change in moisture content from the wet to the dry and from the dry to the wet condition.

- The cumulative length change when in the wet or in the dry condition, based on the original lengths for the initial wet and for the initial dry condition. d The long axis of $A$ specimens was parallel to the vertical dimension of the unit as used on the wall.

- The long axis of $B$ specimens was parallel to the horizontal dimension of the unit as used on the wall. 
When stored in water, in the oven, and in the desiccator, the specimens were racked about $1 / 2$ in. apart, with their long axes horizontal. When in the oven the long axes were parallel to the direction of air flow. The heated air passed over trays of ealcium chloride before meeting the specimens. Although the oven was operated with all doors and vents closed, it was noted that the relative humidity of the air in it fluctuated with changes in the relative humidity of the outside air.

The time interval required to make comparator observations in duplicate was short, and it was noted that the specimens tended to decrease slightly in length (about $0.0001 \mathrm{in.}$ ) after removal from the water and to increase slightly in length after removal from the desiceator.

In this paper the moisture movement is defined as the linear change produced by a change in moisture content from the wet to the dry and from the dry to the wet condition. The length changes are defined as the cumulative changes in length of the specimen when wet and when diy, based on the original length for the initial wet and the initial oven-dry conditions, respectively.

The cyclical moisture movements and length changes that were produced by wetting and drying were much more affected by slight changes in the relative humidity of the air in the drying oven than by changes in the temperature of the air and water. The moisture con tent of the wet specimens was usually about the same for each cycle, and the data obtained from measurements of the specimens when wet were more consistent than those obtained from them when dry. The length changes when either dry or wet, listed in column 14,15 , and 16 of table 7 were dependent upon the relative dryness (or wetness) of the specimens on the initial and all later cycles of wetting and drying. The data showed that the moisture movement and the lengths of the samples tended to become progressively smaller with continued wetting and drying.

The coefficients of variation for the moisture movement of samples 14, 12, and 11 are listed below. The listed coefficients are the average of the coefficients for length change produced by changes in moisture content during the 8 to 10 half-cycles, wet to dry and dry to wet, that are listed in table 7 .

\begin{tabular}{|c|c|}
\hline Sample & $\begin{array}{l}\text { Variability } \\
\text { of shingle } \\
\text { average a }\end{array}$ \\
\hline 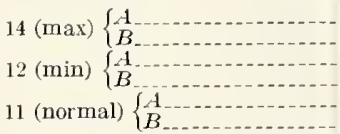 & $\begin{array}{r}11.7 \\
11.9 \\
3.9 \\
4.4 \\
3.7 \\
5.0\end{array}$ \\
\hline
\end{tabular}

a The average of a group of 8 to 10 coefficient determinations, each representing an average for a group of 5 shingles.

\section{(c) Warping}

The warping, or change in curvature, of the siding samples was observed in specimens 6 in. wide and 11 in. long. Each sample was represented by four specimens, two of $A$ and two of $B$. One $A$ and one $B$ specimen was cut from each of two units.

Curvature of the specimens was observed after an initial drying, after wetting and after a second drying. Each drying consisted of storage for 2 days in an oven at $122^{\circ} \mathrm{F}\left(50^{\circ} \mathrm{C}\right)$ and 2 days in a desiccator containing potassium acetate at about $80^{\circ} \mathrm{F}\left(27^{\circ} \mathrm{C}\right)$. The relative liumidity of the air in the oven at the time the specimens were removed was about 33 percent. The wetting exposure consisted of immersion in water at about $73^{\circ} \mathrm{F}\left(23^{\circ} \mathrm{C}\right)$ for 2 days.

The specimens were supported in a horizontal position on a device, figure 2 , and is described in detail in the following section. A micrometer dial placed under the center of each specimen was used to measure the curvature. One end of the specimen was placed in contact with a positioning frame, not shown in figure 2 .

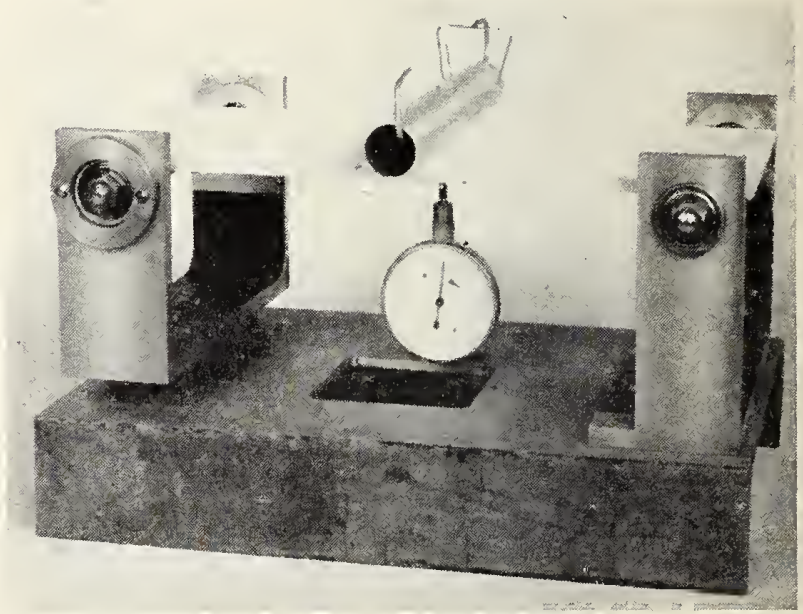

FiguRE 2. Load support for flexural tests.

Each measurement consisted of two observations. One observation was made with exposed (outer) face of the specimen up and the other with the exposed face down. The difference between the two dial readings was halved to obtain the deflection at the center of the specimen. The curvature of the specimens is defined as the reciprocal of the average radius of curvature in inches, which was calculated from the deflection. The curvature and the warping or change in curvature produced by wetting and drying the specimens are listed in table 8, for specimens $17(\max ), 2(\min )$, and 4 (normal). A positive value for the curvature indicated that the exposed face of the specimen was convex, curved outward. 
TABLE 8. Warping of siding samples ${ }^{a}$

\begin{tabular}{|c|c|c|c|c|c|c|c|c|c|c|}
\hline \multirow{3}{*}{ ple } & \multicolumn{6}{|c|}{ Curvature b } & \multicolumn{4}{|c|}{ Change in curvature - b } \\
\hline & \multicolumn{2}{|c|}{ After initial drying } & \multicolumn{2}{|c|}{ After wetting } & \multicolumn{2}{|c|}{ After final drying } & \multicolumn{2}{|c|}{ On wetting } & \multicolumn{2}{|c|}{$\begin{array}{l}\text { From initial to } \\
\text { final drying }\end{array}$} \\
\hline & 1 & $B$ & 2 & $B$ & $A$ & $B$ & $A$ & $B$ & $A$ & B \\
\hline $\begin{array}{r}17 \\
2 \\
4\end{array}$ & $\begin{array}{l}\text { Inch-1 } \\
\text { c+0.0004 } \\
+.0006 \\
-.0009\end{array}$ & $\begin{array}{l}\text { Inch-1 } \\
\mathrm{c}-0.0004 \\
\mathrm{c}-.0002 \\
-.0003\end{array}$ & $\begin{array}{l}\text { Inch-1 } \\
+0.0030 \\
\mathrm{c}+.0006 \\
-.0017\end{array}$ & $\begin{array}{l}\text { Inch-1 } \\
+0.0018 \\
\mathrm{c}-.0002 \\
-.0014\end{array}$ & $\begin{array}{l}I n c h^{-1} \\
{ }^{\mathrm{c}}+0.0004 \\
\mathrm{c}+.0006 \\
-.0010\end{array}$ & $\begin{array}{l}\text { Inch-1 } \\
\mathrm{c}-0.0001 \\
0-.0002 \\
-.0005\end{array}$ & $\begin{array}{l}\text { Inch-1 } \\
+0.0026 \\
+0 \\
-.0008\end{array}$ & $\begin{array}{l}\text { Inch-1 } \\
+0.0022 \\
0 \\
-.0011\end{array}$ & $\begin{array}{l}\text { Inch-1 } \\
\quad 0 \\
0 \\
-.0001\end{array}$ & $\begin{array}{c}\text { Inch-1 } \\
+0.0003 \\
0 \\
-.0002\end{array}$ \\
\hline
\end{tabular}

a Each value represents the average obtained from tests on 2 specimens of $A$, and on 2 of $B$. The long axes of the $A$ specimens were parallel to the vertical dimension of the unit, as used on the wall. The long axes of the $B$ specimens were normal to this dimension.

b The eurvature is the reeiprocal of the radius of eurvature, in inches. A positive value of curvature indieates that the exposed face of the unit was convex.

- The face of 1 of the 2 speeimens was convex, that of the other specimen was eoncave. The values are the algebraic mean of the curvatures.

The greatest change in curvature occurred on wetting the specimens from the dry condition. Most of the specimens tended to regain their original shape on the final drying, after wetting. Specimens from sample 2 did not warp on wetting and drying for both the $A$ and the $B$ specimens. $A$ specimens, cut from samples 5, 7, 10, and 19 , warped in a different direction than clid the $B$ specimens.

\section{Flexural Strength and Extensibility Under Flexural Load}

The strength and extensibility in flexure of the siding samples were determined from tests on specimens $6 \mathrm{in}$. wide and about $11 \mathrm{in}$. long. Each sample was represented by at least 40 specimens divided in to 8 groups of 5 or more specimens each. At least five different units were used in making the specimens for each group. Four of the eight groups contained $A$ specimens only and 4 contained $B$ specimens. Other variables between the groups were the positions of the exposed face of the specimens on the loading support, face up or face down, and the moisture content of the specimens at the time of test. Specimens in the dry condition were dried in an oven at $221^{\circ}$ to $239^{\circ} \mathrm{F}$ $\left(105^{\circ}\right.$ to $\left.115^{\circ} \mathrm{C}\right)$ for 1 day and were cooled to room temperature in a desiccator before being. tested. Wet specimens were immersed in water at room temperature for 1 day before being tested.

The loading support for the specimens is illustrated in figure 2. The specimens were supported on $1 / 2-$ in. round steel bars spaced $10 \mathrm{in}$. apart, center to center. The ends of the bars were inserted in and supported by ball bearings, which permitted the bars to rotate. The supporting base under one bar was rounded, permitting the bar and its support to rock slightly in a vertical plane normal to the span. The radius of curvature of the base was equal to the height of the top of the bar above the base. A micrometer dial reading to $0.001 \mathrm{in}$. was fastened to the loading: plane, and was in contact with the bottom of the specimen at midspan. The flat, circular top of the dial plunger in contact with the bottom of the specimen had a diameter of $1 / 4 \mathrm{in}$.

A 1-in.-diameter aluminum tube was fastened to the head of the testing machine, and load was applied to the specimens on a line at the center of the span. The load was applied continuously to the specimens at the rate of $20 \mathrm{lb} / \mathrm{min}$ until failure occurred. Deflection observations were made at zero load and at each load increment of $2 \mathrm{lb}$. Failure of the specimens was not sufficiently abrupt to damage the micrometer dial. The specimens were tested on a Southwark hydraulic testing machine equipped with a dial having a load range of 0 to $240 \mathrm{lb}$. The maximum loads are listed in table 9 for samples 8,2 , and 13 . 'The loads were corrected for a nominal specimen width of $6 \mathrm{in}$.

TABLE 9. Corrected maximum flexure loads a

\begin{tabular}{|c|c|c|c|c|c|}
\hline \multirow[b]{2}{*}{ Condition } & \multirow[b]{2}{*}{ Speeimen } & \multirow[b]{2}{*}{ Face } & \multicolumn{3}{|c|}{ Sample } \\
\hline & & & $\stackrel{8}{(\max )}$ & $\stackrel{2}{2}$ & $\begin{array}{c}13 \\
\text { (nor- } \\
\text { mal) }\end{array}$ \\
\hline Dry b... & $\left\{\begin{array}{l}A_{-} \\
P_{-}\end{array}\right.$ & $\begin{array}{l}\left\{\begin{array}{l}\text { Up } \\
\text { Down }\end{array}\right. \\
\left\{\begin{array}{l}\text { Up } \\
\text { Down }\end{array}\right.\end{array}$ & $\begin{array}{c}l b \\
\mathrm{~d} 65.8 \\
66.7 \\
\mathrm{~d} 57.4 \\
51.9\end{array}$ & $\begin{array}{c}l b \\
25.2 \\
25.9 \\
33.4 \\
30.4\end{array}$ & $\begin{array}{c}76 \\
39.9 \\
38.1 \\
37.7 \\
37.0\end{array}$ \\
\hline Wet ${ }^{\circ}$ & $\left\{\begin{array}{l}A_{-} \\
B_{-}\end{array}\right.$ & $\begin{array}{l}\left\{\begin{array}{l}\mathrm{U} p \\
\text { Down }\end{array}\right. \\
\left\{\begin{array}{l}\text { Up } \\
\text { Down }\end{array}\right.\end{array}$ & $\begin{array}{r}45.5 \\
46.9 \\
35.2 \\
\text { d } 34.9\end{array}$ & $\begin{array}{l}22.0 \\
20.5 \\
31.6 \\
26.1\end{array}$ & $\begin{array}{r}25.2 \\
24.3 \\
23.9 \\
\text { d } 21.3\end{array}$ \\
\hline Coeffieient 0 & iation & & 10 & 10 & 8 \\
\hline
\end{tabular}

a A verage maximum load for 5 specimens, 1 specimen from each of 5 shingles, unless otherwise noted. The spceimens were 6 in. wide and were loaded on a line at the center of a 10-in. span. The loads are eorreeted for a nominal 6-in. width.

6-in. Width.

c Immersed in water at room temperature for 1 day.

d A verage for 10 shingle specimens. A seeond parcel of 5 was tested when the dispersion of the loads on the initial group was high.

e Average coefficient for the 8 groups of specimens.

\section{(a) Strength}

Strength of the wet specimens was approximately 70 percent of that of the dry specimens. Specimen groups from some samples were con- 
sistently stronger when the direction of bending was parallel to either the vertical or the horizontal dimension of the units ( $A$ or $B$ specimens). Again, in some cases, the specimen groups for some samples were consistently stronger when the specimens were tested either with the face up or down. However, the effect of moisture content on the strength of the specimens was the only consistent relation applying to all samples.

The coefficients of variation for the loads on groups of like specimens were calculated for all samples but are listed in table 9 for only samples 8, 2, and 13 . The coefficients, averaged for all sample groups, were not consistently higher or lower for any particular group, such as specimen $A$ or $B$, tested when dry or wet or face up or down.

It is likely that the flexural strengths of some $B$ specimens that were cut from some units with simulated wood grain were somewhat reduced by the graining. Significant and consistent differences between the strengths of $A$ and $B$ specimens cut from the same sample probably resulted from an oricntation of the asbestos fibers in one direction or another. For samples 1, 2, 3, 10, and 11, the groups of $B$ specimens were 25 percent or more stronger than were similar groups of the $A$ specimens. For samples 5, 6, and 7, groups of the $A$ specimens were markedly stronger than were similar groups of the $B$ specimens. From an examination of the data obtained from wetting and drying all samples, it was noted that for samples $1,2,3,10$, and 11 , the moisture movement for the $B$ specimens was less than that for the $A$ specimens and for samples 5,6, and 7 , the moisture movement for the $A$ specimens was less than that observed for the $B$ specimens. Further data on this matter are found in table 6 for sample 3 . The average linear expansion of the $3, A$, specimens was 50 percent greater than that of the $3, B$, specimens. These observations on the effects of fibcr orientation on flexural strength and on moisture movement correlate those previously found and discussed in the excellent British Technical Paper 29. (See footnote 1, p. 1.)

The average modulus of rupture is listed in table 10 for samples 12,2 , and 3 . As the thickness at the line of break of the specimens was not measured, the values are only approximate. The thickness used in the calculations was measured as described for method 1 (section III-1) and was equal to the average minimum thickness of five units taken at random from each sample. These thicknesses are listed in table 1.
TABLE 10. Modulus of rupture ${ }^{\text {s }}$

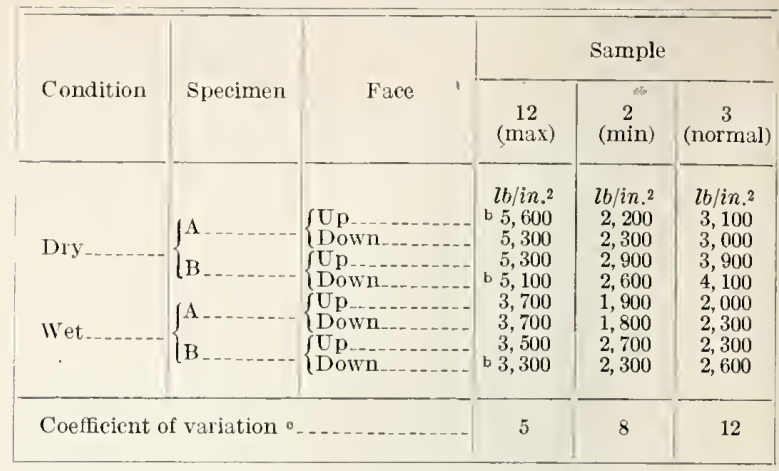

- a Average for 5 specimens, 1 from each of 5 shingles, unless otherwise noted.

cb A verage for tests on 10 shingle specimens.

$A$ verage cocfficient for the 8 groups of specimens.

\section{(b) Extensibility}

The average deflection at maximum load is listed in table 11 for samples 16, 20, and 13 and was estimated from the load-deflection data obtained from tests of the flexure specimens. Although the deflection at maximum load of the specimens tested in a wet condition averaged about 77 percent of the deflection of the dry specimens, the average deflection per pound of maximum load was about 10 percent higher for the wet than for the dry specimens.

TABLE 11. Estimated deflection at maximum load a

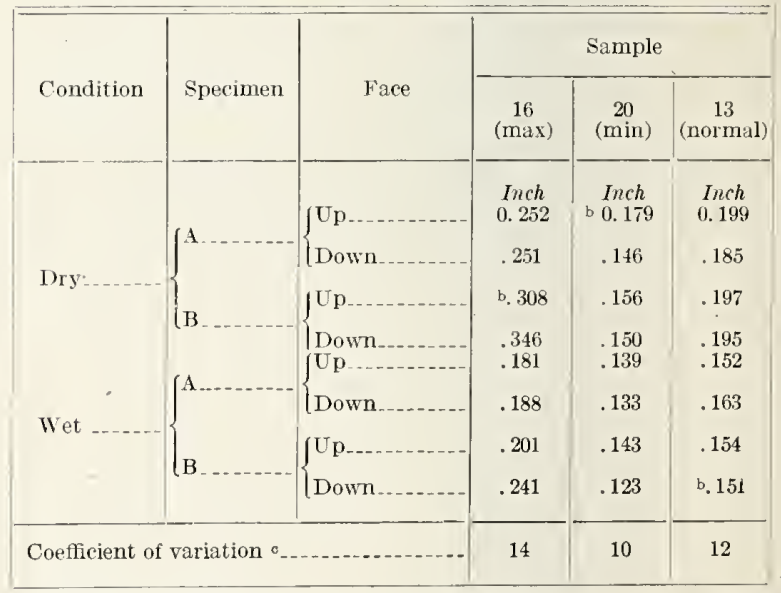

a A verage for 5 specimens, 1 from each of 5 shingles, unless otherwise noted. b A verage for tests on 10 shingle specimens.

c Average coefficient for the 8 groups of specimens. 
The deflection of the specimens at loads less than the maximum may be determined by interpolation with greater accuracy than the deflection at maximum load. If the deflection is to be used in specifications as a measure of the extensibility of siding units, it is probable that the deflection at loads slightly under the maximum load rather than the deflection at maximum load would give a more accurate measure of extensibility. The deflection of the samples at loads equal to 80 percent of the maximum loads are listed in table 12 for samples 16,23 , and 18 .

TABLe 12. Deflection at 0.8 maximum load a

\begin{tabular}{|c|c|c|c|c|c|}
\hline \multirow{2}{*}{ Condition } & \multirow{2}{*}{ Specimen } & \multirow{2}{*}{ Face } & \multicolumn{3}{|c|}{ Sample } \\
\hline & & & $\begin{array}{c}16 \\
(\max )\end{array}$ & $\begin{array}{c}23 \\
\text { (min) }\end{array}$ & $\begin{array}{c}18 \\
\text { (normal) }\end{array}$ \\
\hline Dry & $\begin{array}{l}\left\{\begin{array}{l}A_{\ldots} \ldots \\
B_{\ldots}\end{array}\right. \\
\left\{\begin{array}{l}A \ldots \\
B_{\ldots}\end{array}\right.\end{array}$ & 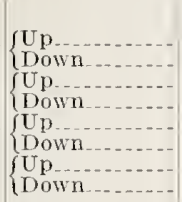 & $\begin{array}{l}\text { Inch } \\
0.181 \\
.181 \\
\mathrm{~b} .218 \\
.241 \\
.123 \\
.122 \\
.142 \\
.156\end{array}$ & $\begin{array}{l}\text { Inch } \\
0.118 \\
.115 \\
.113 \\
.119 \\
.102 \\
.094 \\
.095 \\
.087\end{array}$ & $\begin{array}{l}\text { Inch } \\
0.162 \\
\text { b. } 149 \\
.145 \\
.135 \\
.123 \\
.110 \\
.115 \\
.109\end{array}$ \\
\hline \multicolumn{3}{|c|}{ Coefficient of variation ${ }^{c}$} & 14 & 9 & 13 \\
\hline
\end{tabular}

A combined measure of both strength and extensibility of siding samples that may also be suitable for use in specifications is the product of the maximum load and the deflection at 80-percent maximum load. These products are listed in table 13 for samples $8,4 x$, and 13 .

TABLE 13. Product of the maximum load and the deflection at 0.8 maximum load a

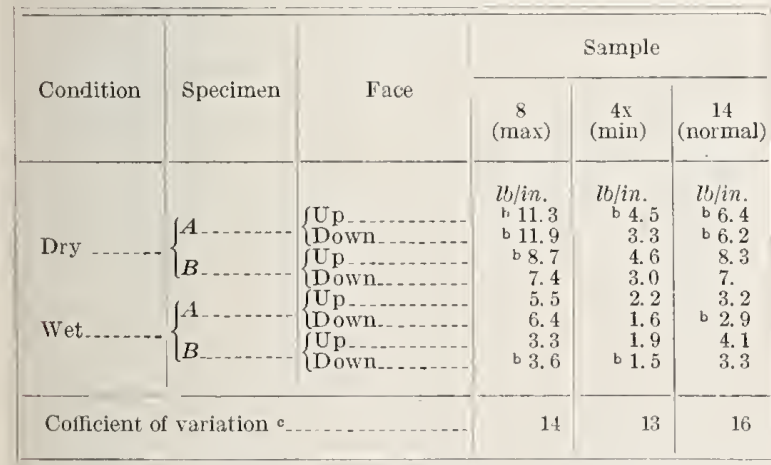

a Arerage for 5 specimens, one from each of 5 shingles, unless otherwise noted.

b A verage for tests on 10 shingle specimens.

c Average coefficient for the 8 groups of specimens.

\section{(c) Modulus of Elasticity}

The secant modulus of elasticity of the samples, calculated at the maximum and at 80 percent of the maximum loads, is listed for samples 12,2 , and 17 in tables 14 and 15 , respectively. The thickness used in calculating the modulus was assumed equal for all specimens from any one sample. This thickness was the same as that used in calculating the modulus of rupture, tablo 10. As the variation in thickness between individual specimens was ignored, the values may be slightly in error. The modulus of elasticity of specimens tested in a dry condition was consistently greater than that for the wet specimens and, as may be expected, was greater at loads of 80 percent of the maximum than at the maximum loads.

TABLE 14. Secant modulus of elasticity at maximum flexure load a

\begin{tabular}{|c|c|c|c|c|c|}
\hline \multirow{2}{*}{ Condition } & \multirow{2}{*}{ Specimen } & \multirow{2}{*}{ Face } & \multicolumn{3}{|c|}{ Sample } \\
\hline & & & $\underset{(\max )}{12}$ & $\stackrel{2}{(\min )}$ & $\stackrel{17}{\text { (normal) }}$ \\
\hline Dry -- & $\begin{array}{l}\left\{\begin{array}{l}A \ldots \\
B_{\ldots} \ldots\end{array}\right. \\
\left\{\begin{array}{l}A_{\ldots} \ldots \\
B_{\ldots} \ldots\end{array}\right.\end{array}$ & $\begin{array}{l}\left\{\begin{array}{l}\text { Up } \\
\text { Down }\end{array}\right. \\
\left\{\begin{array}{l}\text { Up } \\
\text { Down }\end{array}\right. \\
\left\{\begin{array}{l}\text { Up } \\
\text { Down }\end{array}\right. \\
\left\{\begin{array}{l}\text { Up } \\
\text { Down }\end{array}\right.\end{array}$ & $\begin{array}{c}\text { Kips/in. }{ }^{2} \\
\text { b } 3,500 \\
3,400 \\
3,500 \\
\text { b } 3,600 \\
2,900 \\
2,700 \\
2,900 \\
2,700\end{array}$ & $\mid \begin{array}{c}\text { Kips/in.2 } \\
\text { b } 1,300 \\
\text { b } 1,400 \\
1,500 \\
1,400 \\
1,300 \\
\text { b } 1,200 \\
1,500 \\
1,600\end{array}$ & $\begin{array}{c}\text { Kips/im.2 } \\
2,500 \\
1,900 \\
2,300 \\
2,300 \\
2,300 \\
1,700 \\
2,500 \\
2,100\end{array}$ \\
\hline Coeffici & ra. & & 8 & $10 i$ & 21 \\
\hline
\end{tabular}

a A verage for 5 specimens, 1 from each of 5 shingles, unless otherwise noted. b Average for tests on 10 shingle specimens.

c A verage for the 8 groups of specimens.

TABLE 15. Secant modulus of elasticity at 0.8 maximum flexure load a

\begin{tabular}{|c|c|c|c|c|c|}
\hline \multirow{2}{*}{ Condition } & \multirow{2}{*}{ Specimen } & \multirow{2}{*}{ Face } & \multicolumn{3}{|c|}{ Sample } \\
\hline & & & $\frac{12}{(\max )}$ & $\stackrel{2}{2}$ & $\begin{array}{c}17 \\
\text { (normal) }\end{array}$ \\
\hline Dry - & $\begin{array}{l}\left\{\begin{array}{l}A \ldots \\
B \ldots\end{array}\right. \\
\left\{\begin{array}{l}A \ldots \\
B \ldots\end{array}\right.\end{array}$ & $\begin{array}{l}\left\{\begin{array}{l}\text { Up... } \\
\text { Down }\end{array}\right. \\
\left\{\begin{array}{l}\text { Up } \\
\text { Down }\end{array}\right. \\
\left\{\begin{array}{l}\text { Up } \\
\text { Down }\end{array}\right. \\
\text { \{p..... } \\
\text { Uown }\end{array}$ & $\begin{array}{c}\text { Kips/in. }{ }^{2} \\
\text { b } 1,100 \\
3,800 \\
3,800 \\
\text { b, } 300 \\
3,300 \\
3,200 \\
3,400 \\
3,100\end{array}$ & $\begin{array}{c}\text { Kips/2n. }{ }^{2} \\
\text { b } 1,500 \\
\text { b } 1,600 \\
1,700 \\
1,600 \\
1,500 \\
\text { b } 1,400 \\
1,800 \\
1,600\end{array}$ & $\begin{array}{c}\text { Kips/in.2 } \\
2,700 \\
2,390 \\
2,600 \\
2,500 \\
2,600 \\
2,100 \\
2,800 \\
2,600\end{array}$ \\
\hline \multicolumn{3}{|c|}{ Coefficient of variation ${ }^{c}$-. } & 6 & 15 & 18 \\
\hline
\end{tabular}

a Average for 5 specimens, 1 from each of 5 shingles, unless otherwise noted. b A verage for tests on 10 shingle specimens.

A Average for the 8 groups of specimens.

The coefficients of variation for the modulus of elasticity at maximum load were significantly greater than the coefficients for the modulus at 80 percent of maximum load. 'The differences between the coefficients for the modulus of elasticity determinations may be due, in part, to the difficulty of properly estimating the deflection at maximum load.

A somewhat consistent relation was found between the absorption of the samples and their 
modulus of elasticity. The modulus increased with decreases in the absorption. Samples having absorptions of 16 percent or over had secant moduli at loads of 80 percent of the maximum of $2,200,000 \mathrm{lb} / \mathrm{in}^{2}$ or less. From the investigation described in the British Paper 29, it was found that frost resistance of roofing shingles varied with their absorption and initial modulus of elasticity. The frost resistance decreased as the absorption increased and as the modulus of elasticity decreased. These relations may provide a key to the probable weathering resistance of a siding sample without resorting to either artificial or actual weathering-exposure tests.

\section{Tests made by the British Building Research Board}

The effects of weathering on the physical properties of British asbestos-cement roofing products were observed on samples of roofing shingles ${ }^{ \pm}$flat sheets and corrugated sheets and are described in Building Research Technical Paper 29. ${ }^{5}$ Some of the test methods described in T.P. 29, and the effects of natural and accelerated weathering are briefly discussed below. Data obtained from similar tests on British roofing and American siding samples are compared.

\section{Laboratory Measurements}

(a) Flexure Tests

Most of the flexural tests were made on 1- by 7 -in. saturated specimens loaded at the center of a 6-in. span. Some of the tests were made on 10- by 10 -in. saturated specimens loaded on a line at the center of a 9-in. span, in accordance witl the method described in British Standard Specification BS 690. ${ }^{6}$ The fiber direction was usually parallel to the direction of bending and the flexural strength of the flat specimens was greatest in this direction. 'The values of Young's moduhus of elasticity of dry specimens was obtained by a dynamic method from the resonant frequencies of forced longitudinal vibration. In a few cases the values of Young's modulus were checked by using data obtained in the bending tests, and good agreement was obtained.

The failing load on the 1 - by 7 -in. specimens of roofing shingles ranged between 12 and $20 \mathrm{lb}$. The maximum loads on saturated specimens 6 in. wide, cut from samples of American siding and loaded on a line at the center of a 10-in. span ranged between 17 and $47 \mathrm{lb}$, with an average value of $27 \mathrm{lb}$. The roofing shingles (British) and the siding shingles (American) were about the same thickness, so that for an approximate comparison of flexural strength it is only necessary to correct for the differences in the width and length of the specimens. On such a corrected basis, the relative flexural strengtl of the roofing shingles and of the siding samples was 2 to 1 . A similar comparison of flexural strength was ob-

\footnotetext{
4 Designated as slates or flat slates in T. P. 29.

5 Building Researeh Technical Paper 29 may be purchased for 30 cents from the British Information Services, Sales Department, 30 Rockefeller Plaza, New York 20, N. Y.

${ }^{6}$ British Standard 690:1945 Asbestos Cement Slates and Sheets may be purchased for 90 cents from the Amcrican Standards Association, 70 E. 45 th Street, New York 17, N. Y.
}

tained from the modulus of rupture. The average modulus of rupture for two samples of roofing shingles was $5,600 \mathrm{lb} / \mathrm{in}^{2}{ }^{2}$, and the average modulus for the siding samples was $2,900 \mathrm{lb} / \mathrm{in}^{2}$ The average modulus of rupture for two samples of corrugated sheets (table 9 of T. P. 29) was 3,900 lb/in. ${ }^{2}$

The values of Young's modulus of elasticity given in tables 3 and 5 of T. P. 29 range from about 2 to 2.5 million $\mathrm{lb} / \mathrm{in} .^{2}$ for dry specimens of flat and corrugated sheets to values between 2.8 and 3.9 for dry roofing shingles. The average modulus of elasticity of dry specimens cut from siding shingles was 2.6 million $\mathrm{lb} / \mathrm{in} .^{2}$, and the maximum value was 4 million $\mathrm{lb} / \mathrm{in}^{2}{ }^{2}$ The modulus of elasticity for the American siding slingles was generally less than that for the roofing shingles and greater than that for flat and corrugated sheets.

\section{(b) Tensile Tests}

The specimens for tensile strength tests were $6 \mathrm{in}$. long and had a minimum width of $3 / 4 \mathrm{in}$. at the center. They were held at the ends by steel wedge grips. The tensile strength of saturated specimens cut from corrugated sheets was approximately $1,700 \mathrm{lb} / \mathrm{in}^{2}$ (table 2 of T. P. 29).

\section{(c) Impact Tests}

Tests of impact strength were made on specimens 3 in. long and 1 in. wide. The bottom $1 \frac{1}{2} \mathrm{in.}$ of each specimen was clamped in a modified Izod machine and broken with a single blow. The impact strength of wet specimens cut from flat slates and from corrugated sheets reported in T. P. 29 (table 9) averaged 15 and $18 \mathrm{lb} / \mathrm{in.}^{2}$, respectively.

\section{(d) Water Absorption}

The method of determining water absorption used in the accelerated weathering tests was as follows: Specimens $7 \mathrm{in}$. long and $3 \mathrm{in}$. wide were dried for $48 \mathrm{hr}$ at $221^{\circ} \mathrm{F}\left(105^{\circ} \mathrm{C}\right)$ in an electric oven and weighed. They were then placed in a steel vessel evacuated to a pressure of approximately $5 \mathrm{~mm}$ of mercury, and the pressure was maintained at that value for $1 \mathrm{hr}$. Water was then admitted to cover the specimens. After immersion for 7 days the specimens were taken out, wiped to remove surface water, and weighed. 
This test was designed to give maximum values of absorption, and it differs from the test incorporated in the British Standard 690 . In that test, the specimens are immersed in water for 18 hours and dried in an oven at $302^{\circ} \mathrm{F}\left(150^{\circ} \mathrm{C}\right)$ for $4 \mathrm{hr}$. However, the values obtained by the two test methods are very similar.

In tables 5, 6, and 8 of 'T. P. 29 the range in the absorption of roofing shingles, flat sheets, and corrugated sheets are

Roofing shingle Flat sheets

15 to 29 percent by dry weight. 20 to 25 percent by dry weight. Corrugated sheets_._._ 22 to 30 percent by dry weight.

The average water absorption of the American siding samples during a 7 -day immersion period was 16 percent. The maximum absorption was 28 percent and the minimum was 11 percent. These absorptions are comparable to those of the roofing shingles and less than those of the flat sheets and corrugated sheets (British).

\section{(e) Moisture Movement}

The lengtli chang'es produced by alternate wetting and drying were observed on specimens 7 in. long and $3 \mathrm{in}$. wide. The measurements were made with a screw-gage micrometer head supported in a metal frame and reading to $0.0001 \mathrm{in}$. The specimens were dried in an electric oven at $50^{\circ} \mathrm{C}\left(122^{\circ} \mathrm{F}\right)$ and were cooled to room temperature in a desiccator. They were wetted by immersion in water. Some tests consisted of 240 to 480 cyles of alternate wetting and drying. One cycle of wetting and drying was completed in 1 day. In other tests the specimens were dried for $96 \mathrm{hr}$ and immersed for 7 days. The results of the wetting and drying exposures and measurements are described in section IV of T. P. 29.

\section{Effects of Natural Weathering}

Three types of corrugated asbestos-cement sheets were laid on a roof at the Building Research Station and a portion of them were removed from the roof and tested at intervals of $3,6,10$, and 14 years. Visual observation of the corrugated sheets disclosed the collection of dirt and moss growth that was typical of roofing shingles on older buildings. Cut and broken edges of the corrugated sheets were faded from the original light-gray color to a drab light yellow. The discoloration was producted by the carbonation of lime.

The strength tests indicated that the modulus of rupture and the tensile strength were not adversely affected during 10 years of roof exposure. The impact strength was greatly reduced and, after 14 years of exposure, was about one-half that of the initial value.

The moisture movement (change in linear dimensions from the dry to the wet condition) was measured after roof exposures of $1,2,18$, and 22 months duration. The initial movement de- creased with increase in the duration of roof exposure. Sheets placed on the roof 1 month after manufacture showed higher subsequent shrinkage than sheets aged 2 months before they were exposed.

\section{Effects of Accelerated Weathering}

\section{(a) Wetting and Drying}

Length changes: The length changes and moisture movements induced by alternate wetting and drying were affected by carbonation of the specimers and by their age when first tested. 'The effects of carbonation on moisture movement of the specimens and on length were shown by changing the carbon dioxide content of the drying atmosphere. For example, one group was dried in an atmosphere free of $\mathrm{CO}_{2}$ gas. Other groups were exposed to carbon dioxide gas while drying or were dried in air. In general, carbonation tended to reduce the moisture movement and both the dry and wet length of the specimens.

The amount of moisture movement and the length of the specimens were also said to be affected by a continued hydration of the cement and the effects by hydration on length were of opposite sign to those produced by carbonation. Specimens subjected to cycles of wetting and drying 10 weeks after manufacture tended to increase in length when dry. When first dried and wetted at an age of 20 weeks or more, the specimens showed a decrease in dry and in wet length. For example, the data in 'T. P. 29 (table 12) for roofing shingles subjected to 70 cycles of wetting and drying in air indicated the following:

\begin{tabular}{|c|c|c|}
\hline \multirow{2}{*}{$\begin{array}{c}\text { Age when } \\
\text { test began }\end{array}$} & \multicolumn{2}{|c|}{$\begin{array}{c}\text { Length ehange at } 70 \\
\text { cycles }\end{array}$} \\
\cline { 2 - 3 } & Dry & Wet \\
\hline Weeks & $\begin{array}{c}\% \\
9 \\
20 \text { to } 24\end{array}$ & $\begin{array}{c}\% \\
-0.09\end{array}$ \\
& -06 & -.08 \\
\hline
\end{tabular}

The effects of age on dry length, as indicated above, were not greatly changed by increasing the number of cycles of wetting and drying from 70 to 240 or more. 'There was a slight, but significant, further decrease in wet length.

The moisture movement during the initial cycle of wetting and drying in air of roofing shingles ranged between 0.17 and 0.25 percent (fig. 2 of T. P. 29). The morement for the initial cycle of American siding shingles ranged between 0.06 and 0.17 percent. The data obtained from only four or five cycles of wetting and drying specimens cut from the siding shingle indicate changes in length and in moisture morement that were similar to those found for the aged samples of roofing shingles (British). For a like number of cycles of wetting 
and drying it is probable that the magnitude of the length changes and moisture movements of the roofing shingles would be equal to or greater than those for the siding shingles.

Water absorption: The initial water absorptions of the roofing shingles was about equal to that of the siding shingles. The absorption tended to decrease with increase in number of cycles of wetting and drying. After several hundred cycles of wetting and drying in air, the range in water absorption of the slates dropped from an initial value of 15 to 23 percent to a range of 5 to 15 percent (fig. 3 of T. P. 29).

Transverse strength. The transverse strength of 1- by 7-in. specimens cut from roofing shingles increased appreciably during the first 70 cycles of wetting and drying in air (fig. 4 of 'T. P. 29). Above 70 and up to 480 cycles, a small but significant increase in transverse strength was noted. It is probable that some carbonation of the specimens occurred during the wetting and drying and that some of the increase in transverse strength may have been caused by carbonation. This is indicated by tests made on specimens exposed to carbon dioxide gas. The transverse strength of the specimens was increased about 20 percent by carbonation, and the impact strength was reduced about 20 percent, (table 9 of T. P. 29).

Modulus of Elasticity. Young's modulus of elasticity for roofing shingles, flat sheets, and corrugated sheets increased during the first 60 cycles of wetting and drying in air, (table 3 of T. P. 29). No change in the modulus was noted between the 60th and the 180th cycles. The initial modulus of elasticity for two dry samples of roofing shingles was 3.1 million $\mathrm{lb} / \mathrm{in} .^{2}$; at 60 cycles of wetting and drying the average value was 3.55 million $1 \mathrm{~b} / \mathrm{in}^{2}$.

\section{(b) Acid Rain Water}

The attack of acid rain water was observed to have a surface effect, and the extent of attack was measured as the ratio of the loss in weight to surface area. Rain water containing carbon dioxide produced a weight loss in specimens of roofing shingles of about $0.1 \mathrm{~g} / \mathrm{cm}^{2}$ during an immersion period of 50 weeks (fig. 6 of T. P. 29). The rate of attack on roofing shingles of a rain water spray containing 0.05 percent by weight of sulfur dioxide was about $0.07 \mathrm{~g} / \mathrm{cm}^{2}$ in 6 weeks. A solution of humic acid in rain water had little effect on the specimens. The loss in weight produced by acid rain water did not appear to be affected by the absorptive properties of the specimens.

\section{(c) Frost Action}

The effects of freezing and thawing were observed on specimens $7 \mathrm{in}$. long and 1 in. wide. The specimens were frozen in air over night at $5^{\circ} \mathrm{F}\left(-15^{\circ} \mathrm{C}\right)$ and thawed by immersion in water.

Determinations of modulus of elasticity were carried out up to 140 cycles of freezing and thawing. The value of the modulus approached a maximum irrespective of whether or not marked deterioration occurred in the specimens. The deterioration was mainly lamination accompanied by flaking of the specimen.

In general, the frost resistance was highest for specimens having a high initial modulus of elasticity and a low absorption.

\section{Conclusions}

1. As little information was available r'egarding the method of manufacture of the American siding samples or about the kinds of materials used in them, it was not possible to correlate these factors with the data obtained from the tests.

2. Samples of the American siding shingles and of the British roofing shingles had similar absorptive properties.

3. The most practical method of measuring the thickness of the siding samples was the measurement of average thickness by a wa ter-displacement method.

4. The initial rate of water absorption through the cut edges of specimens cut from the siding samples appeared to be much greater than the initial rate through the faces or backs of the specimens.

5. Some samples of siding showed little or no increase in length on exposure to high-pressure steam. There was no correlation between the water absorption and the increase in length of samples exposed to high-pressure steam.

6. The lengths of the samples when wet and when dry tended to become progressively smaller with cycles of alternate wetting by immersion in water and drying in an oven. This was also true of the amount of moisture movement or change in length with change in moisture content. The length changes and the reduction in the moisture movement were attributed to atmospheric carbonation of the specimens. Carbonation of British roofing products, which resulted from both natural and artificial weathering exposures, had similar effects and tended to increase the flexural strength and to decrease the impact strength of the specimens.

7. Some of the siding samples showed little or no change in curvature on wetting and drying, 
and most of the samples tended to regain their original form on drying after immersion in water. Some samples were warped badly before testing.

8. The flexural strength of British roofing shingles was about double that of the American siding shingles and Young's modulus of elasticity for the roofing shingles was significantly greater.

9. Samples of the siding shingles were about 45 percent stronger when tested in the dry condition than when tested in the wet or saturated condition. The deflection per pound of load was slightly greater for the wet than for the dry specimens.

10. When the strength of the siding units was significantly affected by the direction of bending, the moisture movement was least in the direction giving the greatest flexural strength. 'The differences in flexural strength and in moisture movement on testing in different directions was probably due to an orientation of the asbestos fibers in the specimens.

11. The tests indicated that the flexural strengtl of siding samples could be determined more easily by measuring the maximum flexural load than by calculating the modulus of rupture. Similarly, the extensibility under flexural load could be determined more accurately by measuring the deflection at loads slightly less than the maximum than by estimating or attempting to measure the deflection at the maximum, or critical load. 'The product of the maximum load and the deflection at about 80 percent of the maximum load may be a satisfactory measure of both strength and extensibility.

12. The sirling samples having a high specific gravity also tended to have a low water absorption. The modulus of elasticity was greatest for samples having low water absorption.

13. The resistance to freezing and thawing of Britisl roofing products increased with increase in the modulus of elasticity and with decrease in absorption. These correlations (between absorption properties, modulus of elasticity and resistance to freezing and thawing) may possibly be used as an index for measuring the probable durability of cement-asbestos building products.

Acknowledgment is made to Joseph M. Cameron of the Statistical Engineering Laboratory, Division of Applied Ma thematics, for his able assistance in obtaining an estimate of the variability found among the different shingles and of the precision of the test methods used; to Melvin R. Herrmann for his lielp in preparing the paper; and to Norman A. Seese, Jr., for his assistance in the testing of the specimens.

Washington, May $15,1950$. 


\section{BUILDING MATERIALS AND STRUCTURES REPORTS \\ [Continued from cover page i1]}

BMS32 Structural Properties of Two Brick-Concrete-Block Wall Constructions and a Concrete-Block Wall Construction Sponsored by the National Concrete Masoliry Association

BMS33

B.MS34

BMS35

BMS36

Plastic Calking Materials

Performance Test of Floor Coverings for Use in Low-Cost Housing: Part 1.......

Stability of Sheathing Papers as Determined by Accelerated Aging

Structural Properties of Wood-Frame Wall, Partition, Floor, and Roof Constructions With "Red Stripc" Lath Sponsored by The Weston Paper and MIanufac-

Structual Properties of "Palisade Homes" Constructions for Walls, Partitions, and

BMS37 Floors, Sponsored by Palisade Homes

BMIS38

Structural Properties of Two "Dunstone" Wall Consiructions Sponsored by the W. E. Dunn Manufacturing Co

BMS39

Structural Properties of a Wall Construction of "Pfeifer Units" Sponsored by the

Wisconsin Units Co

BMS40 sored by IKnap America, Inc .

BMISt1

BMS42

Effect of Heating and Cooling on the Permeability of Masonry Walls
Structural Properties of Wood-Frame Wall and Partition Constructions with "Celotex" Insulating Boards Sponsored by The Celotex Corporation .

BMS 43

BMSt4

BMS45

BMS46

Performance Test of Floor Coverings for Use in Low-Cost Housing: Part 2.....

Surface Treatment of Steel Prior to Painting

Air Infiltration Through Windows Floors, and Roofs Sponsored by The Globe-TVernicke Co

BMIS 47

BMS48

Structural Properties of Prefabricated Wood-Frame Constructions for Walls, Partitions,

and Floors Sponsored by American Houses, Inc Sponsored by the Homasote $\mathrm{Co}_{2}$

BMS 49

BMS50

B.IS51

Metallic Roofing for Low-Cost House Construction

Stability of Fiber Building Boards as Determined by Accelerated Aging

Structural Properties of "Tilecrete Type A" Floor Construction Sponsored by the Tilecrete Co

BMS52

BMS53

BMS54

BMS55

BMIS56

BMS57

BMS58

BMS59

BMS60

BMS61

BMS62

BMS63

BMS64

BMS65

BMS66

BMS67

BMIS68

BMIS69

BMIS70

BMIS71

BMIS72

BMIS73

BMS74

Effect of Ceiling Insulation Upon Summer Comfort
Structural Properties of a Masonry Wall Construction of "Munlock Dry W"all Brick" Sponsored by the Munlock Engineering Co

Effect of Soot on the Rating of an Oil-Fired Heating Boiler

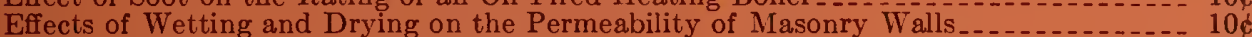

A Survey of Humidities in Residences

Roofing in the Unitcd States-Results of a Questionnaire

Strength of Soft-Soldered Joints in Copper Tubing

Properties of Adhesives for Floor Coverings

Strength, Absorption, and Resistance to Laboratory Freezing and Thawing of Building Bricks Produced in the United States _.

Structural Properties of Two Nonreinforced Monolithic Concrete Wall Constructions. 10

Structural Properties of a Precast Joist Concrete Floor Construction Sponsored by the Portland Cement Association.

Moisture Condensation in Building Wals

Solar Heating of Various Surfaces

Methods of Estimating Loads in Plumbing Systems

Plumbing Manual _ _

Structural Properties of "Mu-Steel" Prefabricated Sheet-Steel Constructions for Walls, Partitions, Floor, and Roofs, Sponsored by Herman A. Mugler .

Performance Test for Floor Coverings for Use in Low-Cost Housing: Part 3...... 20

Stability of Fiber Sheathing Boards as Determined by Accelerated Aging

Asphalt-Prepared Roll Roofings and Shingles.

Fire Tests of Wood-and Metal-Framed Partitions _.

Structural Properties of "Precision-Built, Jr." Prefabricated Wood-Frame Wall Construction Sponsored by the Homasote Co.

Indentation Characteristics of Floor Coverings

Structural and Heat-Transfer Properties of "U. S. S. Panelbilt" Prefabricated SheetSteel Constructions for Walls, Partitions, and Roofs Sponsored by the Tennessee Coal, Iron \& Railroad Co

BMS75

B.IS76

B.IS77

Survey of Roofing Materials in the Sorth Central States

Effect of Outdoor Exposure on the Water Permeability of Masonry Walls.

Properties and Performance of Fiber Tile Boards

Structural Heat-Transfer, and Water-Permeability Properties of Five Earth-IFall Constructions

Water-Distributing Systems for Buildings

Performance Test of Floor Covcrings for Use in Low-Cost Housing: Part $4 \ldots$

Ficld Inspectors' Check List for Building Constructions (cloth cover, $5 \times 71 \frac{1}{2}$ inches).--30

BMS80

BMS81

[List continued on cover page Iv]

-Out of print. 


\section{BUILDING MATERIALS AND STRUCTURES REPORTS}

[Continued from cover page III]

BMS82

BMS83

BMS84

BMS85

BMS86

BMS87

BMS88

BMS89

BMS90

BMS91

BMS92

B MS93

BMS94

BMS95

BMS96

BMS97

BMS98

BMS99

BMS100

BMS101

BMS102

BMS103

BMS104

BMS105

BMS106

BMS107

BMS108

BMS109

BMS1 10

BMS111

BMS112

BMS113

BMS114

BMS115

BMS116

BMS117

BMS1 18

BMS119

BMS120

BMS121

BMS122

BMS123

BMS124
Water Permeability of Walls Built of Masonry Units.

Strength of Sleeve Joints in Copper Tubing Made With Various Lead-Base Solders...

Survey of Roofing Materials in the South Central States...........................

Dimensional Changes of Floor Coverings With Changes in Relative Humidity and Temperature-_tural, Heat-Transfer, and Water-Permeability Properties of "Speedbrik" Wall Construction Sponsored by the General Shale Products Corporation.

A Method for Developing Specifications for Building Construction-Report of Subcommittee on Specifications of the Central Housing Committee on Research, Design and Construction
Recommended Building Code Requirements for New Dwelling Construction With Special Reference to War Housing-.- "Precision-Built, Jr." (Second Construction) Prefabricated Wood-Frame Wall Construction Sponsored by the Homasote Co........... Structural Properties of "PHC" Prefabricated Wood-Frame Construction for Walls, Floors, and Roofs Sponsored by the PHC Housing Corporation A Glossary of Housing Terms

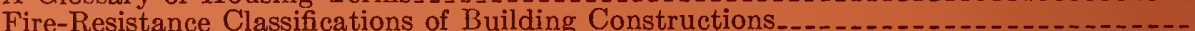
Accumulation of Moisture in Walls of Frame Construction During Winter Exposure.. Water Permeability and Weathering Resistance of Stucco-Faced, Gunite-Faced, and "Knap Concrete-Unit" Walls

Tests of Cement-Water Paints and Other Waterproofings for Unit-Masonry Walls.-. Properties of a Porous Concrete of Cement and Uniform-Sized Gravel ............ Experimental Dry-Wall Construction With Fiber Insulating Board..... Physical Properties of Terrazzo Aggregates for Walls, Floors, and Roofs

Relative Slipperiness of Floor and Deck Surfaces. Strength and Resistance to Corrosion of Ties for Cavity Walls . Painting Steel

Measurements of Heat Losses From Slab Floors Structural Properties of Prefabricated Plywood Lightweight Constructions for Walls, Partitions, Floors, and Roofs Sponsored by the Douglas Fir Plywood Association. Paint Manual with particular reference to Federal Specifications Laboratory Observations of Condensation in Wall Specimens... Building Code Requirements for New Dwelling Construction Temperature Distribution in a Test Bungalow With Various Heating Devices..... 10 Strength of Houses: Application of Engineering Principles to Structural Design Paints for Exterior Masonry Walls _. Performance of a Coal-Fired Boiler Converted to Oil Properties of Some Lightweight-Aggregate Concretes With and Without an Airentraining Admixture Fire Resistance of Structural Clay Tile Partitions Temperature in a Test Bungalow With Some Radiant and Jacketed Space Heaters.-.A Study of a Baseboard Convector Heating System in a Test Bungalow . . Preparation and Revision of Building Codes._. Fire Resistance of Walls of Lightweight-Aggregate Concrete Masonry Units..... The Stack Venting of Plumbing Fixtures. Wet Venting of Plumbing Fixtures..... Fire Resistance of Walls of Gravel-Aggregate Concrete Masonry Units........ Investigation of Failures of White-Coat Plasters . . Physical Properties of Some Samples of Asbestos-Cement Siding Fire Tests of Wood-Framed Walls and Partitions With Asbestos-Cement Facings.-Fire Tests of Steel Columns Protected With Siliceous Aggregate Concrete.......... , 